Illinois State University

ISU ReD: Research and eData

Theses and Dissertations

3-31-2014

\title{
A Quantitative Examination Of Known Exonernations And The Factors That Have Contributed To The Wrongful Convictions Of Innocents
}

Meagan Andrea Semmelroth

Illinois State University, goozlez@gmail.com

Follow this and additional works at: https://ir.library.illinoisstate.edu/etd

Part of the Criminology Commons, and the Criminology and Criminal Justice Commons

\section{Recommended Citation}

Semmelroth, Meagan Andrea, "A Quantitative Examination Of Known Exonernations And The Factors That Have Contributed To The Wrongful Convictions Of Innocents" (2014). Theses and Dissertations. 113. https://ir.library.illinoisstate.edu/etd/113

This Thesis is brought to you for free and open access by ISU ReD: Research and eData. It has been accepted for inclusion in Theses and Dissertations by an authorized administrator of ISU ReD: Research and eData. For more information, please contact ISUReD@ilstu.edu. 


\title{
A QUANTITATIVE EXAMINATION OF KNOWN EXONERATIONS AND THE FACTORS THAT HAVE CONTRIBUTED TO THE WRONGFUL CONVICTIONS OF INNOCENTS
}

\author{
Meagan A. Semmelroth \\ 66 Pages \\ May 2014 \\ Wrongful convictions have been gaining attention both in the public and \\ academic arenas. The knowledge that has been gained about wrongful convictions has \\ been gained mostly by looking at cases of exonerations based on factual innocence. The \\ use of DNA in the adjudication process, mainly in helping to defend and free innocent \\ people brought the detriments of wrongful convictions into the lives of the public through \\ the use of media. Since this time, innocence projects have opened, more cases of \\ exonerations have been found, and more cases of wrongful conviction have been \\ overturned. However, the frequency with which wrongful convictions occurs is yet \\ unknown.
}

This thesis examined the most current, inclusive database of exonerations in the United States that exists, the National Registry of Exonerations. Qualitative and Quantitative data were examined and refined, and many statistical analyses were run including descriptives, frequencies, correlations, and linear regressions in order to gain a better idea of contributing factors, or what occurs in the criminal justice process that can lead to wrongful convictions. There are six categories of contributing factors that are 
widely used in wrongful conviction research. These are eyewitness misidentification, false confessions, perjury and/or false accusations, false and/or false forensic evidence, official misconduct, and inadequate legal defense. This thesis examined wrongful convictions through the lens of contributing factors in order to gain a better idea of what goes wrong so that preventive measures can be put into place to lower the number of innocents who are convicted. 


\section{A QUANTITATIVE EXAMINATION OF KNOWN EXONERATIONS AND THE FACTORS THAT HAVE CONTRIBUTED TO THE WRONGFUL CONVICTIONS OF INNOCENTS}

MEAGAN A. SEMMELROTH

A Thesis Submitted in Partial Fulfillment of the Requirements for the Degree of

MASTER OF SCIENCE

Department of Criminal Justice Sciences

ILLINOIS STATE UNIVERSITY 
(C) 2014 Meagan A. Semmelroth 


\section{A QUANTITATIVE EXAMINATION OF KNOWN EXONERATIONS AND THE FACTORS THAT HAVE CONTRIBUTED TO THE WRONGFUL CONVICTIONS OF INNOCENTS}

MEAGAN A. SEMMELROTH

COMMITTEE MEMBERS:

Michael C. Gizzi, Chair

Jason Ingram

Ralph Weisheit 


\section{ACKNOWLEDGMENTS}

First and foremost, I wish to thank Dr. Michael Gizzi, chair of the thesis committee, for his ongoing support, assistance, and encouragement throughout the thesis process. I will be forever grateful for what he helped me learn and for his constant and vigilant support. I also wish to thank Dr. Jason Ingram and Dr. Ralph Weisheit for their guidance and support as members of the thesis committee. To know that they were there for timely assistance meant the world to me. The team at the National Registry of Exonerations, particularly Maurice Possley, provided regular updates that allowed the data to stay current, and for this I am very appreciative. I also wish to thank Dr. Jacqueline Schneider, head of the Criminal Justice Sciences Department at Illinois State University, for her steady encouragement. She is one of the finest people, both on a personal and professional level, whom I have had the pleasure of knowing and working with. The entire Criminal Justice Department at Illinois State University has become a second family, and I am so thankful for them. Finally, I wish to thank my entire family for their encouragement, understanding, and support. In particular, I would like to thank my parents, Chris and Kim Semmelroth, for their steady encouragement, love, and understanding throughout the entire writing process and Brutus Semmelroth for his love, patience, and for always listening. 


\section{CONTENTS}

Page

ACKNOWLEDGMENTS

CONTENTS

TABLES $\quad$ iv

CHAPTER

I. INTRODUCTION 1

II. REVIEW OF THE LITERATURE 4

Definition of Wrongful Convictions $\quad 4$

Background of Wrongful Convictions 6

Innocence Projects 8

Contributing Factors and Wrongful Convictions $\quad 10$

Contributing Factors: General 11

Contributing Factors: Eyewitness Misidentification 13

Contributing Factors: False Confessions 16

Contributing Factors: Perjury/False Accusation 17

Contributing Factors: False/Misleading Forensic Evidence $\quad 19$

Contributing Factors: Official Misconduct 21

Contributing Factors: Inadequate Legal Defense 23

III. RESEARCH DESIGN 25

Research Questions $\quad 25$

Research Methods $\quad 27$

Examination of the Research Questions 32 
IV. ANALYSIS OF THE DATA 36

Introduction $\quad 36$

Research Question \#1: Characteristics of Known Exonerations 36

Research Question \#2: Correlations of the Contributing Factors 40

Partial Correlations of the Contributing Factors in Selected Crime-Types

Research Question \#3: Time to Exoneration 51

V. SUMMARY, CONCLUSIONS, AND RECOMMENDATIONS 55

Summary of the Research Problems, Methods and Findings 55

Summary of Findings and Recommendations for Future Research $\quad 57$

Conclusions and Implications 62

$\begin{array}{ll}\text { REFERENCES } & 64\end{array}$ 


\section{TABLES}

Table $\quad$ Page

1. Variables in Database 30

2. Descriptive Statistics of Study Variables $(N=1107)$

3. Kendall's Tau-b Bivariate Correlation of the Contributing Factors $(N=$ 1107)

4. Pearson's Bivariate Correlation of the Contributing Factors $(N=1107) \quad 42$

5. Partial Correlation of the Contributing Factors $(N=1107)$

6. Partial Correlation of Factors for Homicide Cases $(N=538)$

7. Partial Correlation of Contributing Factors for Robbery Cases $(N=66) \quad 46$

8. Partial Correlation of Contributing Factors for Sexual Assault Cases $(N=$ 223)

9. Partial Correlation of Contributing Factors for Child Sex Abuse Cases $(N=$ 131)

10. Partial Correlation of Factors for Nonviolent Crimes $(N=104)$

11. Partial Correlation of Contributing Factors for Other Violent Crimes $(N=$ 45)

12. Linear Regression Results of Contributing Factor Variables and Control Variables Predicting Years from Conviction to Exoneration $(N=1107)$ 


\section{CHAPTER I}

\section{INTRODUCTION}

Before the first man was exonerated by DNA evidence in 1989, many people believed that the justice system very rarely convicted the wrong person. When undeniable proof was given that not only had he been wrongfully convicted and imprisoned, but that the crime for which he had suffered had never in fact occurred, it sparked a striking change in the way that wrongful convictions were viewed. Both public interest and academic research in wrongful convictions increased dramatically (Gross, et al., 2005). The public started giving more credence to claims of innocence, and the number of nonprofits trying to help those men and women who have been wrongfully convicted skyrocketed (Krieger, 2011). This newfound focus on wrongful convictions has led to a significant rise in the number of exonerations both in cases involving and not involving DNA evidence every year since (Gross, et al., 2005; see also Radelet, Bedau, \& Putnam, 1992).

However, even with the work nonprofit organizations have done, and the research that has been conducted in the last twenty-four years, the number of exonerations continues to rise. As Gross and Shaffer (2012) say about their database of exonerations, The National Registry of Exonerations, "these cases merely point to a much larger number of tragedies that we do not know about." While efforts to catalog wrongful 
conviction cases have compiled more than 1,100 cases to date, and increase by as many as 100 cases every three months (M. Possley, personal communication, April 1, 2013), it may be impossible to ever measure it completely. While researchers have estimated the occurrence of wrongful convictions using a variety of different methodologies, many scholars agree there is no method that can identify the true number of false convictions (Gross, et al., 2005; Ramsey and Frank, 2007; Rattner, 1988; Zalman, Smith, \& Kiger, 2008). This is troubling for the criminal justice community because it makes it more difficult to understand the problem and to create and apply solutions. As Acker and Redlich (2001, p.17) said, "Our limited understanding of the prevalence and causes of wrongful convictions is significant...because it compromises our ability to construct and implement effective policies to prevent, detect, and correct miscarriages of justice.”

It is difficult for researchers in any field to solve a problem when only the tip of the iceberg is visible. However, it is not necessary to know the depth of a problem in order to put preventative measures in place. Therefore, instead of focusing on the frequency of wrongful convictions, it is imperative to look at what errors have occurred in the criminal justice process that have led to known wrongful convictions. Through examining cases where innocent men and women have been exonerated, researchers have identified a number of factors that consistently contribute to wrongful convictions. By understanding these factors in greater detail, it becomes clear where preventive measures need to be taken in the criminal justice process to ensure that wrongful convictions do not transpire in the first place. 
This project uses data from the National Registry of Exonerations, the most current and inclusive database of known exonerations, in order to examine three research questions about the contributing factors of wrongful convictions. The questions that will be explored are: 1 . What are the characteristics of the exonerations in the NRE, particularly how prevalent is each contributing factor? Is this in line with previous research? 2. How do the factors contributing to wrongful convictions correlate with each other? Is this relationship different by crime type? 3. What factors are associated with the number of years from conviction to exoneration? 


\section{CHAPTER II}

\section{REVIEW OF THE LITERATURE \\ Definition of Wrongful Convictions}

The study of wrongful convictions is difficult. There is no one, simple explanation for why the number of wrongful convictions is a dark figure, there are many reasons. First, there is no way of knowing how many people have been wrongly convicted but have never had their name cleared through exoneration. Second, there are no official records kept of exonerations. One cannot merely ask for a list of exonerations in a city, county, or state because such lists do not exist. Therefore, the media become a prime source for researchers and organizations wishing to discover cases of exoneration. Where there is no media attention, the likelihood of discovering an individual's exoneration is slight. Last, for most research on wrongful convictions, the exoneree must have been exonerated based on factual innocence. A convicted offender's claim of innocence is not enough to conclude they were wrongfully convicted.

Someone who has been exonerated based on factual innocence is "a defendant who was convicted of a crime [and] was later relieved of all legal consequences of that conviction through a decision by a prosecutor, a governor or a court, after new evidence of his or her innocence was discovered" (Gross \& Shaffer, 2012, p.6). These are cases in which the person who had been initially convicted was later shown to be definitively 
innocent of the charges against him or her. Whether the new evidence showed the person's innocence (i.e. through DNA testing), another person's guilt (i.e. someone else confessed), or the fact that no crime ever occurred, the end result is that there is an admittance on the part of the government that the wrong person had been previously convicted, and that person's name is completely cleared. This standard, where there is no doubt that the defendant was innocent, is the standard that most researchers use when studying wrongful convictions (Acker \& Redlich, 2001; Borchard, 1932; Colvin, 2009; Gould \& Leo, 2010; Gross, et al., 2005; Huff, Rattner, \& Sagarin, 1986; Poveda, 2001; Rattner, 1988; Zalman, Smith, \& Kiger, 2008).

However, "in law, a wrongful conviction also results from appellate court reversals based on procedural errors that negate the fair trial prerequisite of the Constitution" (Zalman, Smith, \& Kiger, 2008). A person who is acquitted in this way is said to be 'legally innocent'. In acquittals based on legal innocence, the defendant's guilt or innocence has never been established. In other words, the defendant may still have committed the crime, but he or she has been released because of an error which occurred in the criminal adjudication process. Consequently, these types of cases will almost never be included in wrongful conviction research because there is a chance (whether it is large or small) that the defendant should have been convicted. In this study, when the terms 'exoneration' and 'wrongful conviction' are used, they will be referring only to cases of factual innocence. 


\section{Background of Wrongful Convictions}

To better understand and grapple with the current world of wrongful convictions, it is necessary to first understand the history of wrongful convictions. It appears the study of wrongful convictions began with the study of wrongful executions, specifically those where it was later realized that no crime had actually taken place. Starting during the Age of Enlightenment $\left(16^{\text {th }}\right.$ and $17^{\text {th }}$ centuries), English and American scholars began to address the fact that innocent people had been tried, convicted and executed for crimes not only that they had never committed, but crimes that had never in fact occurred. As science and reason took center stage during this period, people began to realize that some crimes and phenomena that had explained using spiritual reasoning may have actually had a rational explanation. Before this time, tradition, religion and superstition were commonly used when something was otherwise inexplicable.

As people began to reject the idea that good and evil forces could explain everything, and instead began to look for rational explanations of phenomena, scholars began to grapple with the idea that perhaps in cases where people had been executed for crimes that had not occurred, an error in the criminal justice process was to blame, not evil. This change in perspective allowed for the darker realization that there was a possibility that truly innocent people had been executed, in turn becoming victims themselves. Therefore, the initial cases examined were cases where people had been adjudicated and executed for murder (based only on circumstantial evidence and a missing person), and then the supposed murder victim had reappeared at a later time alive and well (Smith, 2005). Cases like these made it very difficult to deny the fact that a 
heavy mistake had been made. Consequently, scholars began to look more closely at the criminal justice process. This led to a newfound focus on corpus delecti, or the fact that a crime has actually occurred (Smith, 2005). By creating new standards for proving that a crime had occurred, the hope was that less people would be wrongfully convicted for crimes that never occurred.

\section{William Blackstone's Commentaries on the Laws of England between 1765 and} 1769 states that "All presumptive evidence of felony should be admitted cautiously: for the law holds, that it is better that ten guilty persons escape, than that one innocent suffer" (Smith, 2005, p.4). In 1816, English lawyer Samuel March Phillipps published (in America) "a searing indictment of the dangers of circumstantial evidence in capital case," which showed "the dangers of excessive reliance on circumstantial evidence in capital cases" (Smith, 2005, p.7). Blackstone, Phillipps, and others were calling for a more thorough and rigorous criminal justice system, one where assumptions would not be made about a crime's occurrence or about a person's guilt. These scholars wanted other explanations to be given due consideration before a person's freedom was taken away, a model which points to due process, not crime control. Over the next approximately 250 years, corpus delecti and wrongful convictions were in and out of public awareness, but nothing truly brought them to the attention of the masses until the first DNA exoneration proved to the modern word that the justice system was able to get the verdict wrong.

However, even with DNA evidence, people have been reluctant to admit that wrongful convictions occur. This appears to be particularly true for those who helped achieve those convictions, including prosecutors and the police. Part of this is because it 
is more difficult to prove the wrong man was convicted when a crime has actually occurred. Another reason is that there are so many plea bargains. It is common to assume that no person would accept a plea bargain unless they had committed the crime, just as it is assumed that no one would falsely confess to committing a crime. As Gross and Shaffer (2012, p.57) say, “[m]ost people don’t believe they would ever admit committing a crime of which they were innocent, and many are skeptical that anybody else would." But many innocent people have accepted plea bargains. There are so many plea bargains today that it gives the impression of a smoothly running criminal justice system. There is also the belief among many people that if you are caught up in the criminal justice system at all, you probably deserve it on some level.

It has become easier to convince people that completely innocent people can wind up in the criminal justice system because now there is undeniable proof in the form of DNA analysis. People being exonerated based on DNA evidence (something that is real, tangible and difficult to argue with) convinced many that there were innocent people sitting in prisons, struggling to live with wrongful convictions on their records. In the worst cases people who have been sent to their death for crimes they did not commit (Mumma, 2004).

\section{Innocence Projects}

The first DNA exoneration massively increased interest in wrongful convictions. This led to the creation of innocence projects, organizations that investigate claims of innocence and try to exonerate innocent people who have been convicted of a crime they did not commit. The first of these was Centurion Ministries, INC, which was founded by 
James C. McCloskey in 1983 (Krieger, 2011). Known as the "grandfather" of innocence projects, Centurion Ministries was named after the Roman Centurion from the Bible who stood at the foot of the cross while Jesus was dying and said, "Surely, this one is innocent" (Krieger, 2011). Nine years later, The Innocence Project was founded by Barry Scheck and Peter Neufeld at Cardozo Law School (Acker \& Redlich, 2001). Known as the "father" of the current wave of innocence projects, The Innocence Project now has a staff of fifty people and has become the most recognized of these organizations in the world. They have also been instrumental in the foundation of other innocent projects around the nation, and they have set up resources for other innocence projects. This includes their Innocence Network, which has resources such as their Brief Bank that has briefs about issues other innocence projects may face. The Innocence Project also hosts annual conferences, and it consults with state, local, and federal level law enforcement officials and legislators to improve legislation concerning DNA and nonDNA aspects of the criminal justice system through research, training, and scholarship. Thanks to public concern and organizations like Centurion Ministries and The Innocence Project, there are now more than sixty innocence projects. These organizations fill a void because the private sector does not look into wrongful convictions, and neither does the government. From the perspective of the government convictions are seen as hard and fast answers, and many times the government is unwilling to pursue a claim of innocence (Krieger, 2011). Innocence projects have been vital in educating the public, freeing innocent people, and discovering more about what contributes to wrongful convictions. 


\section{Contributing Factors and Wrongful Convictions}

Researchers point to six main factors that contribute to wrongful convictions: eyewitness misidentification, false confessions, perjury/false accusations, false/misleading forensic evidence, official misconduct, and inadequate legal defense. It may seem odd that DNA does not have its own group, but it is factored in in other ways. For example, if DNA was tested incorrectly or falsified, this falls into the category of "false/misleading forensic evidence." Alternatively, if there was DNA evidence, but it was not tested until after the person was convicted, these data did not contribute to the wrongful conviction, rather the new DNA test contributed to the exoneration. In this situation, DNA testing is seen as the means of discovering the wrongful conviction, not as a contributing factor. Rather, if the case occurred after DNA testing was available, the reason behind why the DNA evidence was never tested is what is counted as the contributing factor. If the case was adjudicated before DNA testing was available, then the lack of DNA testing would not have contributed to the wrongful conviction. Rather, when new DNA evidence coming to light, or old DNA evidence from the original scene is tested, this calls the original conviction into doubt and allows for the investigation of what other contributing factors led to it.

Borchard (1932) was the first scholar to discuss the idea of contributing factors. In addition to those already listed, he also included "faulty circumstantial evidence" and "prosecutorial excesses." Brandon and Davies (1973) included confessions made by "feebleminded" or otherwise "mentally inadequate" persons, and the category of criminals as witnesses. Rattner (1988) looked at other researchers studying wrongful 
convictions and their contributing factors and found that some researchers in the past had used "police and prosecutorial overzealousness" and "police and prosecutorial bad faith" rather than the broader category of "official misconduct." However, all of these factors have been compressed into the initial five contributing factors listed above and have been widely agreed upon as the best five categories into which the contributing factors of wrongful convictions can be grouped.

\section{Contributing Factors: General}

First and foremost, most contributing factors do not occur in a vacuum. Eric Colvin, in his work Convicting the Innocent: A Critique of Theories of Wrongful Conviction (2009) took an exploratory approach to explaining why wrongful convictions occur. Rather than focusing on the legal causes of error (which is what most researchers have discussed), his paper focuses on "causal errors." He argues that in the study of wrongful convictions, there should be a focus on the interaction between two things: 1 . Errors occurring when offenses are investigated and wrongful accusations are made, and 2. Errors in the adjudicative processes that are supposed to correct the earlier errors and prevent wrongful convictions. He says, "[w]rongful accusations do not necessarily lead to wrongful convictions. They lead to wrongful convictions when the safeguards of the criminal justice system fail" (Colvin, 2009). Therefore, he argues strongly against the crime control model. When the criminal justice process is running on the crime control model, it is focused on efficiency and getting criminals of off the street quickly. It essentially assumes that if someone has entered the adjudication stage, they must be guilty. Sheila Berry (2003) said, "[w]hile jurors give lip service to the presumption of 
innocence, most believe the defendant 'must have done something' or the state would not have brought its substantial resources to bear on him" (Berry, 2003, p.488). It is not surprising, then, that Colvin is a strong advocate of the due process model and trying to find the truth and justice for each individual that enters the criminal justice system, as opposed to the crime control model that almost has a 'guilty until proven innocent' mantra.

Colvin (2009) believes that errors made at the investigative stage should be righted in the adjudicative stage, and that in the cases of wrongful conviction, this does not happen. Therefore, it is highly unlikely that one factor alone would explain any single wrongful conviction:

Criminal trials contain an elaborate set of protections against convicting innocent persons: for example, rules respecting the admissibility of evidence; ethical obligations for prosecuting counsel; institutional arrangements for the accused to be legally represented; a requirement for jury unanimity or at least for a heavy majority verdict; and a requirement for guilty to be proved beyond reasonable doubt. These safeguards must fail if a wrongful conviction is to occur. Either an error must be made in their operation or they must be deficient in some feature or features. Every wrongful conviction therefore necessarily involves errors at two stages: in the investigation of the offence when errors lead to wrongful accusation; and in the trial process when the various safeguards for the protection of innocent persons fail to correct the investigative error. (p. 181) 
Huff, Rattner and Sagarin (1986) agree, claiming that wrongful convictions are most likely to occur when there is a breakdown in the system in more than one way. Because of all of these safeguards, Colvin says that wrongful convictions should not only be studied independently, (such as the psychology of eyewitness misidentification), but that other symptoms should also be studied as well such as the police culture of relying on poor identification evidence, practices used when interrogating children (Feld, 2013), or the fact that poor identification evidence makes it through trials. Or, instead of focusing on how unreliable forensic evidence made it into trial, rather study why the defense did not challenge it, or why the judge did not have a safeguard against letting it stand in trial.

Contributing Factors: Eyewitness Misidentification

Eyewitness misidentification has been identified as the leading contributing factor of wrongful convictions by numerous researchers (Borchard, 1932; Gross et al, 2005; Rattner, 1988), and there is a plethora of other research on the various problems with using eyewitnesses in general (Acker \& Redlich, 2001). Where it has not been identified as the leading contributing factor, it is almost always in the top two (Brandon and Davies, 1973). Northwestern University's Center on Wrongful Convictions (2004) identified snitch cases as the leading cause of wrongful convictions in US capital cases at $45.9 \%$. Erroneous eyewitness identification testimony was second most frequent, appearing in $25.2 \%$ of cases, followed by false confessions, found in $14.4 \%$ of cases, and finally false presentation of misleading scientific evidence, found in $9.9 \%$ of cases (Northwestern University School of Law Center on Wrongful Convictions, 2004). 
In 1932, E.M. Borchard qualitatively described 65 cases of wrongful convictions, identifying the contributing factors in each case. He found that the top three contributing factors were eyewitness misidentification, incorrect inferences drawn from circumstantial evidence, and perjury (or a combination of these factors). In 29 out of 65 cases (or 44.6\%), he identified eyewitness misidentification as the main contributing factor of the wrongful conviction. Borchard (1932) talks about how, even then, juries were more willing to give credence to the victim of an outrageous crime and found it hard to tell when they were wrong. Borchard talks about the fact that due to the shock of experiencing a violent crime, many victims cannot correctly identify the offender. In addition, because people want to punish someone for violent crimes, police, prosecutors and triers of fact may put a lot of weight on eyewitness identification...even though in 8 of these cases, the accused and the actual offender looked nothing alike (Borchard, 1932). Acker and Redlich (2001) showed that juries are more likely to give greater credence to confident identifications even though research has shown that the correlation between eyewitness confidence and eyewitness accuracy is extremely weak or nonexistent. This makes sense, however, because people are more likely to believe someone who is confident over someone who is unsure. Justice Brennan, in his dissent in Watkins v. Sowders also agreed with this, saying, "much eyewitness identification evidence has a powerful impact on juries. Juries seem most receptive to, and not inclined to discredit, testimony of a witness who states that he saw the defendant commit the crime" (Watkins v Sowders, 1981, p.558). On top of this, juries do not typically understand the possible errors with eyewitness identification. Nothing of this sort is 
explained to them before they hear a case. Therefore, it is difficult for them to identify when eyewitnesses have made a mistake (Acker and Redlich, 2001). Gross, et al (2005) showed that it is the same for trials in which someone knowingly commits perjury. If the person committing perjury is confident, then the jury is more likely to believe what they say.

Elizabeth Loftus says that "misleading questions and other post-event information can alter what eyewitnesses remember and subsequently report” (Acker \& Redlich, 2001, p.112). Because many witnesses assume (subconsciously or consciously) that their assailant must be in the lineup or photo spread, they choose the person who looks most like the offender. (American Bar Association, 2006). Sequential lineups (showing people/photos one at a time) seems better in theory than showing people six people at once because people should be less likely to choose the person who looks most like the suspect, rather they have to say "yes" or "no" to each person/photo one at a time; however, in the field, standard lineups resulted in higher accuracy. (Acker and Redlich, 2001).

In their research on eyewitness misidentification in lineups, the American Bar Association (2006) showed that police unknowingly (or even knowingly) suggest or encourage the identification of the person they believe to be the culprit. Whether this involves making them question another person in the lineup, or is in some way implying that one person is the correct choice. Another unfortunate shortcoming of eyewitness identification is that witnesses' confidence is likely to go up over time. Therefore, if they are encouraged after the line up (or even directly told) that they chose the "correct" 
person, then even if they chose that suspect tentatively, they will most likely become much more confident in their decision. The American Bar Association study also found that in a cross-racial lineup, it is more likely that the eyewitness will choose the wrong person; whereas in an intraracial lineup, it is more likely that the eyewitness will choose correctly (American Bar Association, 2006).

\section{Contributing Factors: False Confessions}

When a suspect confesses it usually has a dramatic domino effect. Prosecutors, even if there is no corroborating evidence, will probably file charges; defense attorneys will be more likely to assume the guilt of their client and they will start negotiating a guilty plea rather than preparing for trial. If the case goes to trial jurors will view the confession as strong evidence and probably vote to convict, and appellate courts will place more weight on the confession than on any errors that were made during the trial (Acker \& Redlich, 2001). This creates a serious problem for people who have falsely confessed. Borchard (1932) says that even though confessions are often viewed as the truth, they must be thoroughly inspected because, contrary to what many people believe, people can confess to things that they have not done. There are a number of reasons for this. For example, when people with low mental capacities are accused, they may submit to the person accusing them and tend to agree with them. Gross, et al (2005) showed in their research that the most vulnerable groups of innocent defendants are the ones most likely to falsely confess. This includes juveniles, the mentally unstable, and the intellectually disabled. 
Kassin (2008) distinguished three types of false confessions: 'voluntary,' 'compliant,' and 'internalized' false confessions." Voluntary confessions come from a "pathological need for attention or self-punishment, feelings of guilt or delusions, the perception of tangible gain, or the desire to protect someone else" (Kassin, 2008 p.249). This can be seen in celebrated cases where someone confesses for the attention, or in cases, for example, where a girlfriend takes the blame for her boyfriend. Compliant false confessions happen when "the suspect acquiesces in order to escape from a stressful situation, avoid punishment, or gain a promised or implied reward...this confession is an act of public compliance by a suspect who perceives that the short-term benefits of confession outweigh the long-term costs..." (Kassin, 2008 p.249). This can be seen when someone is made to believe that they will get to go home if they just tell the police that they did it. In sad and extreme cases, after the confession, the suspect never actually goes home again. Finally, "internalized false confessions are those in which innocent but vulnerable suspects, exposed to highly suggestive interrogation tactics, not only confess but come to believe they committed the crime in question" (Kassin, 2008 p.249). This is seen most often with intellectually disabled suspects and juveniles, groups that other scholars also say are the most vulnerable (American Bar Association, 2006; Feld, 2013).

\section{Contributing Factors: Perjury/False Accusation}

False accusations are sometimes associated with eyewitness misidentification (Loftus, 2003). When someone identifies to the police a person who was never involved in a crime as being a part of it, they are in turn accusing them of the crime and drawing them into the criminal justice process. "The history of the United States justice system, 
like those of other countries, is littered with wrongful convictions made on the basis of mistaken memories" (Loftus, 2003). False allegations of crimes can also come about from people seeking attention who create a crime in their head and even create possible evidence, but all in the name of getting attention (McNamara \& Lawrence, 2012). They can also come from cases where the accuser creates a scenario in order to protect themselves. In the case of Gary Dotson, his accuser (a teenager in high school) thought she had become pregnant from her boyfriend, so, in a fit of terror, she created a scenario in which she was raped, so that her parents would have someone to blame if she was in fact pregnant. She had no way of knowing that the fake person she described to a forensic sketch artist would eventually lead to the arrest and conviction of an innocent man (Associated Press, 1989). False accusations can also come from snitches or criminal informants, who falsely accuse an innocent person of committing a crime because of the benefit they may receive. Alexandra Natapoff says "every year, tens of thousands of offenders have their own reasons [for becoming an informant], giving the government information to avoid criminal charges or work off their sentences. Some of that information is true; much of it is false, as dozens of exonerations have proved" (Natapoff, 2011, p. 1). Perjury can occur when those people lie under oath, but it can also occur when a government official lies under oath. This would most likely be a forensic analyst or a law enforcement officer and can occur for a number of reasons. Both of these examples will be given greater attention below. 


\section{Contributing Factors: False/Misleading Forensic Evidence}

Radelet, Bedau, \& Putnam's work in 1992 was a kind of catalyst during its time.

Before it, not very much was being written on wrongful convictions. But this work broke down 350 cases of wrongful convictions, what had gone wrong in the adjudication process in each, and how the fact that each was a wrongful conviction had come to be known. Because of this depth and thoroughness, it spurred much more writing in the field. Shortly thereafter, DNA testing's availability and popularity increased dramatically. This created an opportunity for police and prosecutors to start relying solely on DNA during cases, forgetting that wrongful convictions could still happen even with this great tool. However, at the same time groups helping exonerate those claiming to have been wrongly convicted started using DNA as a tool.

The first man exonerated by DNA was Gary Dotson in 1989 (Gross, et al, 2005). Since then, DNA exonerations have been increasing almost every year. Indeed, most exonerations are for rape or murder cases because of the high rate of DNA evidence being available to test (Gross, et al, 2005). DNA (as stated above) was one of the only things that made some people believe that wrongful convictions occurred. DNA testing allowed police to verify they had the right person and for innocent people to prove they had been wrongfully convicted. It encouraged more research on wrongful convictions, and it allowed for people's claims of innocence to be heard. This was true both for those cases that involved DNA and for those cases that did not. Without the increased attention brought to wrongful convictions by DNA, wrongful conviction research and advocacy would not be as advanced as it is today. 
However, the popularity of DNA has highlighted concerns about the criminal justice process not come without its downfalls. First, it has suggested to researchers the likelihood of many more wrongful convictions. As already stated, many exonerations are for rape and murder because there is DNA to test. Yet, Gross, et al say, "If we had a technique for detecting false convictions in robberies that was comparable to DNA identification for rapes, robbery exonerations would greatly outnumber rape exonerations, and the total number of falsely convicted defendants who were exonerated would be several times what we report" (Gross, et al, 2005, p.531). This is a scary idea, but one that would not have come about had it not been for the discovery and admissibility of DNA.

Second, DNA is conclusive. This seems to go against what was said earlier DNA can conclusively eliminate someone as a suspect, or confirm their guilt; each person has their own genetic makeup that cannot be argued for another person's. However, the problem lies in the fact that this is not the case with much other forensic evidence. Nevertheless because of the popularity of DNA and shows like CSI, many people believe that other forensic evidence is just as conclusive, and that there is forensic evidence in all cases. Many are starting to call this the "CSI Effect" (McKay, 2008). Shows such as CSI have given a bit of an unrealistic image of not only what crime scenes are like, but also what forensic labs are like. The reality is that there is not always enough physical evidence at a scene to be tested, and when there is, there is a false sense of the amount of time it takes, and the conclusions that can be gathered from it (McKay, 2008). 
Here again tunnel vision comes into play. When investigators rely too heavily on forensic evidence that could have come from the victim or the offender, or they do not approach all avenues, forensic evidence can end up helping convict an innocent person. For example, if there were three people in a room, and blood spatter and footprints indicate that one of the three murdered the victim, and the third was innocent (even though he was the murderer), there could be other explanations, such as the true murderer was barefoot, so he did not leave footprints, and the innocent person actually tried to help the victim. When police do not explore all avenues, the wrong person can end up paying for it. Even worse is when forensic analysts or police actually falsify or plant evidence that leads to an innocent person's conviction.

\section{Contributing Factors: Official Misconduct}

This category is usually paired with another category when it comes into play in a case. Most often, when an official of the criminal justice system conducts themselves in an unethical manner, either a false confession emerges, or false forensic evidence comes about, or a number of other things happen that can lead to a wrongful conviction. Rarely does official misconduct appear by itself in cases of wrongful conviction. Borchard says that in almost all of the cases, some "fault, carelessness, or overzealousness" can be charged to the police or prosecution (Borchard, 1932, p.369). This includes police overlooking or suppressing evidence, and the prosecution being too overzealous with the evidence which had been presented to them. He also talks about the fact that prosecutors see convictions as victories that will in fact help their reputation, therefore they can only be focused on that and their statistics, not on who is actually guilty. Public opinion is 
another factor that comes into play. When the public is crying for justice, whether it is for the increase of burglaries in the area, or if it is for a particularly heinous crime that happened recently, they just want a scapegoat, they do not necessarily care who it is. District attorneys can feel this pressure and merely just want these cases closed. Huff, Rattner, and Sagarin (1996) sum it up very nicely:

[a]nother motivation that accounts for false confession (and true ones as well) is the pressure on police investigators--whether from press, public, or politicians, or from within the department--to solve cases. This can lead interrogators to have a state of mind in which they are easily prone to believe in any suspect's guilt, even on the flimsiest of evidence. Once convinced of such guilt, they feel justified in resorting to any means, legal or illegal, from brutality to prevarication, from threats to promises that cannot be fulfilled, from trickery to dishonesty (including perjury), in order to prove in court what they already know, in their own minds, to be true- that the suspect committed the crime (Huff, Rattner, \& Sagarin, 1996, p.111).

Tunnel vision is another important topic that has been discussed in terms of official misconduct. Tunnel vision occurs when one forms an idea or comes to a conclusion about something and is so sure that he or she ignores indicators that the conclusion could be wrong while at the same time unknowingly interpreting other data to support it (Rassin, 2010). In terms of interrogations and false confessions, this is the idea that an officer is so sure that a suspect has committed the crime, that they ignore clues that he or she did not do it, and they draw conclusions from other data to show that he or 
she did (no matter how far-fetched these conclusions may be). Rassin gave much evidence that tunnel vision, or confirmation bias, "has been associated with miscarriages of justice" (Rassin, 2010, p.154).

\section{Contributing Factors: Inadequate Legal Defense}

The Sixth Amendment of the U.S. Constitution guarantees the assistance of counsel. Effective assistance of counsel is assumed by most people. The fact that counsel could be ineffective or inadequate seems unlikely to most people, and especially to those outside of the world of criminal justice. It is hard to believe that inadequate legal defense is a problem, and enough of a problem to warrant a slot as one of six contributing factors of wrongful convictions. However, inadequate legal defense is more common than many people think, because most people are not familiar with the goings on of legal counsel. While automatic blame usually goes to public defenders, the private sector may be just as much to blame. Even so, a claim of ineffective legal defense is still gaining credibility in and out of the criminal justice field, particularly with appellate courts. Also, "it is difficult to evaluate work quality in criminal defense because outcomes do not always correlate with effort and client satisfaction is a dubious barometer" (Medwed, 2006, p.133).

The American Bar Association (2008) identified a number of reasons why legal defense may be inadequate. First, the Supreme Court case of Strickland v. Washington (1984), set a standard the defense counsel must meet in order for his or her assistance to be considered effective. "For a court to find that lawyer's trial-level performance was ineffective, the defendant must prove first that the attorney's acts or omissions were 
'outside the wide range of professionally competent assistance'-- judged by an 'objective standard of reasonableness.' Even if trial counsel's performance was unreasonable under this 'competence' prong, the defendant must then prove that 'there is a reasonable probability that, but for counsel's unprofessional errors, the result of the proceeding would have been different"' (American Bar Association, 2006, p.3). Examples of ineffective counsel include sleeping during a large portion of a client's trial (American Bar Association, 2006), commingling client funds (Medwed, 2006), advising a client to take a plea deal after he or she has not checked into alibis or clerical errors, not calling witnesses, and not making critical objections at trial (The National Registry of Exonerations, 2012), only to name a few.

The American Bar Association (2006) also identified case workloads as a cause for inadequate legal defense, a subject that has been heavily written on for some time. The topic of overwhelming workloads of public defenders is not a new one. It has been identified as a problem for a very long time. However, only recently has it really been discussed as something that could lead to wrongful convictions: "[In] a world of set salaries and fees, not to mention limited public respect, many assigned defenders battle to remain motivated and to ward off creeping cynicism toward their own clients' potential innocence" (Medwed, 2006, p.133). Public defenders have an enormous workload, and many of their clients are in fact guilty. Even when he or she is an effective, competent, hardworking lawyer, it would be difficult not to assume the guilt of every client that comes through the door. Based on that assumption a lawyer could be advising an innocent person to take a plea bargain. 


\section{CHAPTER III \\ RESEARCH DESIGN}

\section{Research Questions}

The factors that contribute to wrongful convictions are complex, and often occur in combination with one-another. Most exoneration cases involve more than one factor, making the study of wrongful convictions and their contributing factors even more difficult. It would be much easier if one contributing factor could be isolated and improved upon, but this is not possible. Innocence projects and other organizations that have been inspired by them, and the current focus on wrongful convictions are in place currently to help those who have already been wrongly convicted. This research set out to assist in the prevention of more wrongful convictions from occurring- helping people before a wrongful conviction occurs. The population of past wrongful convictions and the rate at which they occur does not need to be known for preventive measures to be taken. What is important is knowing what has caused known wrongful convictions to occur. This research uses the National Registry of Exonerations to examine three specific questions about wrongful convictions:

1. What are the characteristics of the exonerations in the NRE, particularly how prevalent is each contributing factor? Is this in line with previous research? 
2. How do the factors contributing to wrongful convictions correlate with each other? Is this relationship different by crime type?

3. What factors are associated with the number of years from conviction to exoneration?

First, it is necessary to run frequencies and some basic descriptives on this data set in order to get a better idea of what has been collected. It is important to first show the frequencies of age, race, and crime. Next, the prevalence of each contributing factor will be identified in order to compare it with what previous research says on this topic. Also, looking at the frequency of contributing factors among different crimes and also the frequency of cases that had more than one contributing factor will allow for a more complete understanding of contributing factors and thus of wrongful convictions.

Also worthy of noting is how complex the criminal justice system is, and how these contributing factors interact with one another. During the process of an investigation and adjudication, many elements of the criminal justice system interact with one another. If there is a pattern of certain elements interacting with one another in a way that consistently leads to wrongful convictions, shedding light on this could lead to the prevention of a number of wrongful convictions. The most interesting of these interactions seems to be that of inadequate legal defense with the other factors. From preliminary views of the data, it seems to occur much less frequently than the others. Because it is still gaining credibility in the field, this seems logical. However, by examining this factor further, and where it has interacted with other factors, it will allow 
for further explanation of it, and therefore an increase in its credibility as a contributing factor of wrongful convictions.

Next, the public's focus on wrongful convictions in the last twenty-four years has led to a number of innocent men and women being exonerated. After 1989, interest has consistently increased, as seen by the vast growth of innocence projects. If this increased attention has shortened the average time from an innocent person's conviction to their exoneration, this is worthy of noting. It should bolster efforts by innocence projects and hopefully lead to an even greater interest in building more of them. By examining how the time from conviction to exoneration has changed (if it has), then a better understanding of this field of study can be reached. Also important when examining this is whether or not DNA affects the time from conviction to exoneration, and if it does, how it does so.

\section{Research Methods}

The research proposed here will use an existing data set created by The National Registry of Exonerations (NRE), a joint project of the University of Michigan Law School and the Center on Wrongful Convictions at Northwestern University. The registry is an online database of 1107 (as of May 4, 2013) exonerations identified since 1989. ${ }^{1}$ The registry provides both empirical data on individual cases, as well as qualitative summaries of facts for each case. The registry catalogs exoneration cases that occurred in the United States, and does not provide any comparative data from other nations. It includes cases that were exonerated in 1989 or later, and to qualify, the exonerations must

\footnotetext{
${ }^{1}$ The NRE can be found at http://www.law.umich.edu/special/exoneration/Pages/about.aspx
} 
be based on factual innocence. In order to find these cases, the research team at NRE explores all avenues they can (court records, media sources, networking, etc.) to find cases of exonerations which have taken place in the last twenty-four years. Then, they explore the cases to gather as much information as possible for the database.

Although this database is the most complete database of exonerations, it does have limitations as a research source. It is still unknown how many other wrongful convictions have occurred that are not available in this sample. This database only consists of known cases of exonerations and includes only exonerations that have occurred since 1989. Also, this database consists only of exonerations that have come to the attention of those involved with the NRE. This database only exemplifies a number of the cases that have occurred. However, the cases that this database encompasses are described in full detail. Without this database, the study of wrongful convictions would not be as progressed as it is, and the current research would not be possible. While these limitations are not insignificant, the registry still represents the most comprehensive source of data on wrongful convictions and provides a wealth of data that can be used to examine the questions in this study.

The staff at the NRE has written two reports on the database, one in 2012, and one in 2013. Both have given preliminary analyses of the data they have collected. They touch on many of the same topics that will be discussed in the present research questions; however this thesis will go into much further detail and attempt to give much more in depth explanations of the issues discussed. They have run some of the same frequencies and descriptives that will be run (the current research only includes seventeen more cases 
than the most recent report); however the correlations and linear regressions are specific to this thesis.

Currently the dataset includes 1,107 exoneration cases (as of May 4, 2013). Each case has its own individual page where as much information as possible is given about the crime and the wrongfully convicted person's journey through the criminal justice process. This includes a detailed description in paragraph form and also bulleted information about the case including the state and county in which the case took place, the most serious crime that the exoneree was convicted of and additional convictions (if there were any), the year the crime was reported, the year the exoneree was convicted, the year they were exonerated, the sentence they received, the exoneree's race, sex and age, the contributing factors that led to the wrongful conviction, and whether DNA evidence contributed to the exoneration. Most of this information is also listed in a spreadsheet. The spreadsheet also includes other "tags" that the National Registry of Exonerations has identified as other common characteristics of wrongful convictions. A case can be "tagged" if the co-defendant confessed (implicating the exoneree), if the case was part of a child sex abuse hysteria, if it was a female exoneree, if it was a federal case, if no crime was committed, if the defendant pled guilty, if it was a posthumous exoneration, or if the exoneree was convicted of Shaken Baby Syndrome. The author created a database in SPSS merging information provided in the detailed spreadsheet view with information that was provided only on the individual detail page for each case. Then new variables were created in order for the proper analyses to be run. The variables included can be seen in Table 1: 
Table 1. Variables in Database.

\begin{tabular}{|c|c|}
\hline Last & The last name of the exoneree \\
\hline First & The first name of the exoneree \\
\hline Age & The age on the date the crime was committed \\
\hline Race & The exoneree's race \\
\hline Black & Whether the exoneree was black or not \\
\hline Causasian & Whether the exoneree was Caucasian or not \\
\hline Hispanic & Whether the exoneree was Hispanic or not \\
\hline OtherRace & $\begin{array}{l}\text { Whether the exoneree was another race } \\
\text { (besides black, Caucasian, or Hispanic) or not }\end{array}$ \\
\hline NonWhite & $\begin{array}{l}\text { Whether the exoneree was non-Caucasian or } \\
\text { Caucasian }\end{array}$ \\
\hline County & The county in which the crime was committed \\
\hline State & The state in which the crime was committed \\
\hline Crime & $\begin{array}{l}\text { The crime for which the exoneree was } \\
\text { convicted }\end{array}$ \\
\hline AdditionalConvictions & $\begin{array}{l}\text { Any additional crimes for which the exoneree } \\
\text { was convicted }\end{array}$ \\
\hline Sentence & The sentence the exoneree received \\
\hline MinYR & The minimum sentence the exoneree received \\
\hline MaxYR & The maximum sentence the exoneree received \\
\hline CrimeOccurred & The year in which the crime was reported \\
\hline Convicted & The year in which the exoneree was convicted \\
\hline Exonerated & $\begin{array}{l}\text { The year in which the exoneree was } \\
\text { exonerated }\end{array}$ \\
\hline YrstoExon & $\begin{array}{l}\text { The number of years from the exoneree's } \\
\text { conviction to their exoneration }\end{array}$ \\
\hline After1992 & $\begin{array}{l}\text { Whether the conviction occurred in } 1992 \text { or } \\
\text { before, or in } 1993 \text { and later }\end{array}$ \\
\hline MistakenWitnessID & $\begin{array}{l}\text { Whether or not eyewitness misidentification } \\
\text { was a contributing factor }\end{array}$ \\
\hline FalseConfession & $\begin{array}{l}\text { Whether or not false confession was a } \\
\text { contributing factor }\end{array}$ \\
\hline PerjuryorFalseAccusation & $\begin{array}{l}\text { Whether or not perjury or false accusation } \\
\text { was a contributing factor }\end{array}$ \\
\hline FalseorMisleadingForensicEvidence & $\begin{array}{l}\text { Whether or not false or misleading forensic } \\
\text { evidence was a contributing factor }\end{array}$ \\
\hline
\end{tabular}




\begin{tabular}{|l|l|}
\hline OfficialMisconduct & $\begin{array}{l}\text { Whether or not official misconduct was a } \\
\text { contributing factor }\end{array}$ \\
\hline Inadequate Legal Defense & $\begin{array}{l}\text { Whether or not inadequate legal defense was a } \\
\text { contributing factor }\end{array}$ \\
\hline TotalFactors & $\begin{array}{l}\text { The number of factors that were involved in } \\
\text { leading to the wrongful conviction }\end{array}$ \\
\hline NoCrime & $\begin{array}{l}\text { Whether or not this was a case where no } \\
\text { crime was committed }\end{array}$ \\
\hline GuiltyPlea & $\begin{array}{l}\text { Whether or not the exoneree accepted a guilty } \\
\text { plea }\end{array}$ \\
\hline CoDefendantConfessed & $\begin{array}{l}\text { Whether or not the co-defendant in the case } \\
\text { confessed and implicated the exoneree }\end{array}$ \\
\hline ChildSexabuseHysteria & $\begin{array}{l}\text { Whether or not this case part of a wave of } \\
\text { child sex abuse prosecutions in 1980s and } \\
\text { 1990s }\end{array}$ \\
\hline PosthumousExoneration & $\begin{array}{l}\text { Whether or not the exoneree was exonerated } \\
\text { after they had died }\end{array}$ \\
\hline FemaleExoneree & Whether the exoneree was female or not \\
\hline ShakenBabySyndrome & $\begin{array}{l}\text { Whether or not the exoneree was convicted of } \\
\text { Shaken Baby Syndrome }\end{array}$ \\
\hline FederalCase & Whether or not this was a federal case \\
\hline DNAorig & $\begin{array}{l}\text { Whether or not DNA evidence contributed to } \\
\text { the exoneration }\end{array}$ \\
\hline DNAnotDeterminative & $\begin{array}{l}\text { Indicates if DNA evidence was involved, but } \\
\text { not central to establishing innocence, and } \\
\text { other non-DNA factors were essential to the } \\
\text { exoneration }\end{array}$ \\
\hline Dobbery & $\begin{array}{l}\text { Whether or not DNA evidence was essential } \\
\text { in leading to the exoneration }\end{array}$ \\
\hline SexualAssault & $\begin{array}{l}\text { Whether the most serious crime committed } \\
\text { was homicide or not }\end{array}$ \\
\hline ChildSexAbuse & $\begin{array}{l}\text { Whether the most serious crime committed } \\
\text { was robbery or not }\end{array}$ \\
\hline $\begin{array}{l}\text { Whether the most serious crime committed } \\
\text { was sexual assault or not }\end{array}$ \\
$\begin{array}{l}\text { Whether the most serious crime committed } \\
\text { was child sex abuse or not }\end{array}$ \\
\hline Homicide &
\end{tabular}




\begin{tabular}{|l|l|}
\hline OtherViolent & $\begin{array}{l}\text { Whether the most serious crime committed } \\
\text { was another violent crime (other than } \\
\text { homicide, robbery, sexual assault, or child } \\
\text { sexual abuse) or not }\end{array}$ \\
\hline OtherNonViolent & $\begin{array}{l}\text { Whether the most serious crime committed } \\
\text { was nonviolent or not }\end{array}$ \\
\hline
\end{tabular}

Examination of the Research Questions

First, basic frequencies and descriptives of the data set will be run, including age, race, and gender. This will allow for a basic understanding of what kind of data are available. Next, the frequency of DNA exonerations will be run to see how common DNA evidence has been in exoneration cases since its commencement. Frequencies will be run on cases involving DNA in the exoneration process, and then on only the cases where DNA evidence was determinative in the exoneration. This will give a clearer idea of cases where DNA evidence has truly absolved innocent people in the last twenty-four years. Then, the frequencies of each contributing factors will be run. Understanding what contributing factors have been most frequent allows for a better idea of where more controls need to be put into place in the criminal justice system. Seeing how the contributing factors are different in cases of homicide, murder, sexual assault, child sex abuse, other violent crimes, and nonviolent crimes will allow for an increased understanding of which cases have had the most problems in the past. There are limitations with frequencies and descriptives because this data set could be skewed. For example, eyewitness misidentification could have the highest frequency in this data set; however, it is possible that a different contributing factor, say false confession, in reality has the highest frequency in the population, but not as many cases involving that 
contributing factor have been exonerated. It is nevertheless a good starting point for the analysis of wrongful convictions.

Second, the thesis will consider which contributing factors are more likely to appear together. As Colvin (2009) said, it is not likely for one contributing factor to stand alone in a case of wrongful conviction. Therefore, next to be examined is whether or not there are contributing factors that are more likely than others to appear together when someone is wrongfully convicted. If there are factors that seem to be related and are likely to appear together this sheds light on a gap in the criminal justice process through which innocent people are allowed to slip and become convicted of crimes they did not commit. Knowledge of a gap such as this would be integral in preventing wrongful convictions. If, for example, a false confession is more likely to occur when official misconduct occurs, then it points to a larger issue that needs to be explored through more research. Inadequate legal defense and its interactions with other factors will be explored in more depth because of its infancy in this field. By examining how legal defense is different from the other factors in both frequency and correlation, it will lead to a better explanation and defense of the factor. This factor needs data that show that it belongs on the list of contributing factors of wrongful convictions, and this examination can help do that. Correlations will also be run with each type of crime (homicide, robbery, sexual assault, child sex abuse, other violent crime, and nonviolent crime) in order to see whether or not certain contributing factors are more likely to appear in certain types of cases. 
This question will be examined through the use of a bivariate correlations in order to see how closely related each contributing factor is to one another and to crime types at a statistically significant level. This is the only test that will compare each contributing factors against the other, allowing for the analysis of how they are related. Partial correlations will also be run, controlling for age when the exoneree was convicted, along with race and gender. If there is a difference between the bivariate correlation and the partial correlation, it again points to a larger issue in the system: depending on a person's age, race or gender, they may be more likely to be found guilty in the American criminal justice system.

Last, it is worthy of noting how exonerations have changed over the last twentyfour years. This database begins with cases of exonerations beginning in 1989 (however, there are conviction dates as far back as 1956). DNA evidence led to the first DNA exoneration in 1989, thus popularizing wrongful convictions. The popularization of wrongful convictions led to an increase in innocence projects that help those who have been wrongfully convicted. Has the rise in interest in wrongful convictions allowed the time between conviction and exoneration to decrease since 1989, or is the average time still the same? Once this question has been answered, other possible explanations will also be given (other than an increase in innocence projects). This step is important because if the time between the occurrence of a crime, the detection of the wrongful conviction and an exoneration can be decreased, this is another huge step in bettering the criminal justice process and repairing the public's faith in the criminal justice system. 
This question will be explored by examining the average number of years from conviction to exoneration. A linear regression will be run in order to see what factors impact (increase or decrease) the time from conviction to exoneration. Two models will be used, one with each of the different contributing factors included, and one with only the total number of contributing factors. The variables included in both will be race, crime type (homicide, robbery, sexual assault, child sex abuse, and other violent crime), gender, and whether or not the exoneration was before or after 1992.

1992 is an estimate of the time when DNA should have been demanded more in the trial process. It stands to reason that before 1992, DNA evidence was not demanded in trials because the first DNA exoneration only took place in 1989. Therefore, convictions taking place prior to 1992 were probably more likely to have DNA evidence come out in the exoneration process, not in the adjudication process. 


\section{CHAPTER IV}

\section{ANALYSIS OF THE DATA}

Introduction

This chapter analyzes the results of tests run on the data regarding three research questions:

4. What are the characteristics of the exonerations in the NRE, particularly how prevalent is each contributing factor? Is this in line with previous research?

5. How do the factors contributing to wrongful convictions correlate with each other? Is this relationship different by crime type?

6. What factors are associated with the number of years from conviction to exoneration?

Answers to these three questions may prove useful in preventing future wrongful convictions while keeping the project within the scope of a Masters Thesis, despite previously discussed limitations of the data.

\section{Research Question \#1: Characteristics of Known Exonerations}

To prevent future wrongful convictions, it is necessary to know what has led to wrongful convictions in the past. By examining known characteristics of people who have been wrongfully convicted. First examined are the frequencies and descriptive statistics of the variables in the National Registry of Exonerations at the time of the study. 
Table 2. Descriptive Statistics of Study Variables $(N=1107)$

\begin{tabular}{|c|c|c|c|c|c|c|}
\hline Study Variables & Frequency & Percentage & Mean & S.D. & Min. & Max. \\
\hline \multicolumn{7}{|l|}{ Demographics } \\
\hline Age & 1038 & 93.8 & 27 & 9 & 11 & 83 \\
\hline Female & 74 & 6.7 & & & 0 & 1 \\
\hline Caucasian & 412 & 37.2 & & & 0 & 1 \\
\hline Black & 501 & 45.3 & & & 0 & 1 \\
\hline Hispanic & 128 & 11.6 & & & 0 & 1 \\
\hline Other & 66 & 6.0 & & & 0 & 1 \\
\hline \multicolumn{7}{|l|}{ Contributing Factors } \\
\hline $\begin{array}{l}\text { Perjury/False } \\
\text { Accusation }\end{array}$ & 578 & 52.2 & & & 0 & 1 \\
\hline Official Misconduct & 480 & 43.4 & & & 0 & 1 \\
\hline $\begin{array}{l}\text { Eyewitness } \\
\text { Misidentification }\end{array}$ & 452 & 40.8 & & & 0 & 1 \\
\hline $\begin{array}{l}\text { False/Misleading } \\
\text { Forensic Evidence }\end{array}$ & 249 & 22.5 & & & 0 & 1 \\
\hline $\begin{array}{l}\text { Inadequate Legal } \\
\text { Defense }\end{array}$ & 162 & 14.6 & & & 0 & 1 \\
\hline False Confession & 144 & 13.0 & & & 0 & 1 \\
\hline \multicolumn{7}{|l|}{ Total \# of Factors } \\
\hline 0 & 53 & 4.8 & & & 0 & 1 \\
\hline 1 & 311 & 28.1 & & & 0 & 1 \\
\hline 2 & 450 & 40.7 & & & 0 & 1 \\
\hline 3 & 205 & 18.5 & & & 0 & 1 \\
\hline 4 & 63 & 5.7 & & & 0 & 1 \\
\hline 5 & 24 & 2.2 & & & 0 & 1 \\
\hline 6 & 1 & 0.1 & & & 0 & 1 \\
\hline \multicolumn{7}{|l|}{ DNA Variables } \\
\hline \begin{tabular}{|l} 
DNA (all cases) \\
\end{tabular} & 349 & 31.5 & & & 0 & 1 \\
\hline DNA (determinative) & 301 & 27.2 & & & 0 & 1 \\
\hline \multicolumn{7}{|c|}{\begin{tabular}{|l|l|} 
Convicted Crimes & \\
\end{tabular}} \\
\hline Homicide & 538 & 48.6 & & & 0 & 1 \\
\hline Robbery & 66 & 6.0 & & & 0 & 1 \\
\hline Sexual Assault & 223 & 20.1 & & & 0 & 1 \\
\hline Child Sex Assault & 131 & 11.8 & & & 0 & 1 \\
\hline Other Violent & 45 & 4.1 & & & 0 & 1 \\
\hline Other Nonviolent & 104 & 9.4 & & & 0 & 1 \\
\hline \multicolumn{7}{|c|}{\begin{tabular}{|l|l|} 
Time Variables & \\
\end{tabular}} \\
\hline $\begin{array}{l}\text { Time to Exoneration } \\
\text { (in years) }\end{array}$ & 1107 & 100.0 & 11 & 8 & 0 & 38 \\
\hline After 1992 & 499 & 45.1 & & & 0 & 1 \\
\hline
\end{tabular}


As seen in Table 2, age at time of conviction ranges between 11 and 83 years old, with a mean age of 27 years old and a standard deviation of 9. Almost half $(\mathrm{n}=501$, 45.3\%) of the exonerees were Black, 37.2\% ( $\mathrm{n}=412)$ were Caucasian, $11.6 \%(\mathrm{n}=128)$ were Hispanic, and 6\% ( $\mathrm{n}=66)$ were identified as something other than Black, Caucasian, or Hispanic. Only $6.7 \%(\mathrm{n}=74)$ of exonerees were female. DNA was involved in 349 exonerations, but it was only determinative in 301 of those cases.

Due to the vast amount of previous research naming eyewitness misidentification as the most frequent factor leading to wrongful convictions, the first hypothesis was that eyewitness misidentification would be the most frequent contributing factor in wrongful convictions in the database. However, this did not prove to be true. As seen in Table 2, perjury or false accusation was the contributing factor with the highest frequency, occurring in $52.2 \%$ of cases $(n=578)$. Official misconduct was second, appearing in $43.4 \%$ of cases $(n=480)$, and eyewitness misidentification was third $(40.8 \%, n=452)$. False or misleading forensic evidence was fourth most frequent at $22.5 \%(\mathrm{n}=249)$. Inadequate legal defense was hypothesized to occur least frequently because it is still not completely accepted as a factor; however it was second to last, occurring in $14.6 \%$ of cases $(n=162)$. False confessions actually appeared least frequently, occurring in only $13 \%$ of cases $(n=144)$.

It was also expected that most cases would have one or two contributing factors. This is because it seems unlikely that a case with none of these six universally accepted factors would result in exoneration. If none occurred, it begs the question, what happened that is not covered by these six categories? Also, it seems unlikely that a case 
would have more than two factors contributing to the wrongful conviction. If more than two contributing factors appeared in a case, it seems likely that gross mistakes were made that should have been caught throughout the adjudication process. This hypothesis was supported. As seen in Table 2,68.8\% $(n=761)$, had one or two contributing factors (28.1\% and $40.7 \%$ respectively). Almost $20 \%$ of cases $(n=205,18.5 \%)$ had three factors. There were just $88(8 \%)$ cases with four or more factors $(5.7 \%$ had four, $2.2 \%$ had five, and $.1 \%$ had 6$)$. Surprisingly, 53 cases $(n=4.8 \%)$ had zero of the six contributing factors lead to their wrongful convictions.

The crimes for which the exonerees had been convicted varied widely. In addition to the most serious crime for which the exoneree had been convicted, the data set also included additional crimes for which they had been convicted at the same time. Due to the variety and complexity of the cases in the data set, cases were broken into six crime types based on the most serious crime for which the exoneree had been convicted. ${ }^{2}$ These categories were: homicide, robbery, sexual assault, child sex abuse, other violent crime, and other nonviolent crime. Given the role that DNA has played in exoneration cases, it was hypothesized that homicide and sexual assault cases would be the most prevalent crimes in the data set. These crimes are more likely than others to leave DNA behind. This hypothesis was supported. Homicide cases represented almost half of all cases $(n=538,48.6 \%)$, and sexual assault cases represented another $20 \%(n=223)$. Child sex abuse cases consisted of $11.8 \%$ of the cases $(n=131)$, nonviolent crimes consisted of $9.4 \%(n=104)$, robbery of $6 \%(n=66)$, and other violent crimes of $4.1 \%(n=45)$. As

\footnotetext{
${ }^{2}$ It is important to note that an exoneree may have been convicted of two serious crimes, but only the most serious conviction will not be taken into consideration in this analysis.
} 
Gross, et al (2005) pointed out, if robbery cases had testable evidence equivalent to that of DNA in sexual assault cases, exonerations for robbery cases would probably greatly outnumber those for sexual assault cases. If wrongful convictions for robberies do in fact greatly outnumber those for homicides and sexual assaults, but they are more difficult to exonerate, it would have a significant effect on the known frequency of exonerations if there were a way to physically test these cases.

\section{Research Question \#2: Correlations of the Contributing Factors}

One of the limitations of the National Registry of Exonerations is that the data set is not comprehensive. It is true that there is no comprehensive data set of wrongful convictions because the rate of their occurrence is unknown; however, there are a few issues around which to work when dealing with a data set that is small, not random, and where the population is unknown. Most importantly, these data are not normally distributed, thus only non-parametric tests will be applied. Therefore, when looking for correlations between the contributing factors, the non-parametric Kendall's tau $\mathrm{b}$ bivariate correlation was applied to see whether the existence of one contributing factor could increase or decrease the chance that another would also exist in any given case. 
Table 3. Kendall's Tau-b Bivariate Correlation of the Contributing Factors $(N=1107)$

\begin{tabular}{lllllll}
\hline & 1 & 2 & 3 & 4 & 5 & 6 \\
\hline Eyewitness Misidentification (1) & 1 & & & & & \\
False Confession (2) & $-.185^{* *}$ & 1 & & & & \\
Perjury/False Accusation (3) & $-.515^{* *}$ & -.017 & 1 & & & \\
False/Misleading Forensic Evidence (4) & .006 & .010 & -.004 & 1 & & \\
Official Misconduct (5) & $-.174^{* *}$ & $.079^{* *}$ & $.348^{* *}$ & -.052 & 1 & \\
Inadequate Legal Defense (6) & -.048 & -.046 & -.044 & -.033 & $-.068^{*}$ & 1 \\
\hline
\end{tabular}

**. Correlation is significant at the 0.01 level (2-tailed).

*. Correlation is significant at the 0.05 level (2-tailed).

As can be seen in Table 3, there were quite a few statistically significant correlations. As noted earlier, when official misconduct occurs, it can lead to false confessions. Therefore, it was hypothesized that where official misconduct occurred in a case, false confession would be more likely to occur as well. This hypothesis was supported, although the correlation was small $(\mathrm{r}=.079, \mathrm{p}<.01)$. Official misconduct also had a slight negative correlation with eyewitness misidentification $(\mathrm{r}=-.174, \mathrm{p}<.01)$ and a modest correlation with perjury/false accusation $(\mathrm{r}=.348, \mathrm{p}<.01)$. In other words, where there was evidence of official misconduct there was less likely to be eyewitness misidentification, but a greater chance of perjury or false accusation.

It was also hypothesized that eyewitness misidentification and perjury/false accusation would be positively correlated; however they had a moderate negative correlation $(\mathrm{r}=-.515, \mathrm{p}<.01)$, meaning that where one exists, the other is less likely to occur. Eyewitness misidentification also had a slight negative correlation with false confession $(\mathrm{r}=-.185, \mathrm{p}<.01)$. Where there was inadequate legal defense there was a slightly smaller likelihood of official misconduct $(\mathrm{r}=-.068, \mathrm{p}<.05)$.

Although the results from these bivariate correlations are informative, the author 
wanted to dig deeper and control for other variables. However, in order to run a partial correlation, normally distributed data are needed. Therefore, the author weighed the risk and chose to next run a bivariate correlation on the contributing factors using the parametric Pearson's correlation (as seen in Table 4) to see whether these results would be the same as the Kendall's tau b test. Although this has limitations, the author accepted the risk that only if the non-parametric and parametric test results were identical would partial correlations then be run on the data. They were in fact identical; therefore a partial correlation was next run on the data set controlling for age, race and $\operatorname{sex}^{3}$.

Table 4. Pearson's Bivariate Correlation of the Contributing Factors $(N=1107)$.

\begin{tabular}{lllllll}
\hline & 1 & 2 & 3 & 4 & 5 & 6 \\
\hline Eyewitness Misidentification (1) & 1 & & & & & \\
False Confession (2) & $-.185^{* *}$ & 1 & & & & \\
Perjury/False Accusation (3) & $-.515^{* *}$ & -.017 & 1 & & & \\
False/Misleading Forensic Evidence (4) & .006 & .010 & -.004 & 1 & & \\
Official Misconduct (5) & $-.174^{* *}$ & $.079^{* *}$ & $.348^{* *}$ & -.052 & 1 & \\
Inadequate Legal Defense (6) & -.048 & -.046 & -.044 & -.033 & $-.068^{*}$ & 1 \\
\hline **. Correlation is significant at the 0.01 level (2-tailed). & & & & & \\
*. Correlation is significant at the 0.05 level (2-tailed). & & & & & \\
\end{tabular}

Table 5. Partial Correlation of the Contributing Factors $(N=1107)$.

\begin{tabular}{llllllll}
\hline \multicolumn{2}{l}{} & 1 & 2 & 3 & 4 & 5 & 6 \\
\hline Eyewitness Misidentification (1) & 1 & & & & & \\
False Confession (2) & $-.201 * *$ & 1 & & & & \\
Perjury/False Accusation (3) & $-.520^{* * *}$ & -.019 & 1 & & & \\
False/Misleading Forensic Evidence (4) & .046 & -.003 & -.013 & 1 & & \\
Official Misconduct (5) & $-.187 * *$ & $.103 * *$ & $.362 * *$ & -.048 & 1 & \\
Inadequate Legal Defense (6) & $-.083^{* *}$ & -.036 & -.029 & -.030 & -.059 & 1 \\
**. Correlation is significant at the 0.01 level (2-tailed). & & & & & & \\
*. Correlation is significant at the 0.05 level (2-tailed). & & & & &
\end{tabular}

${ }^{3}$ The control variables were "age at time crime occurred", "female exoneree", and "NonWhite". 
As seen in Table 5, when age, race and sex were controlled for, the results changed. The correlation between inadequate legal defense and official misconduct was no longer significant; however the correlation between inadequate legal defense and eyewitness misidentification became significant with a slight negative relationship ( $\mathrm{r}=-$ $.083, \mathrm{p}<.01)$. The other previously significant correlations only changed slightly: the correlation between eyewitness misidentification and false confession was still slightly negative $(\mathrm{r}=-.201, \mathrm{p}<.01$; previously $\mathrm{r}=-.185, \mathrm{p}<.01)$; the correlation between eyewitness misidentification and perjury/false accusation was still modestly negative $(r=-.52, p<.01$; previously $\mathrm{r}=-.515, \mathrm{p}<.01)$; the correlation between eyewitness misidentification and official misconduct was still slightly negative $(\mathrm{r}=-.187, \mathrm{p}<.01$; previously $\mathrm{r}=-.174$, $\mathrm{p}<.01$ ); the correlation between official misconduct and false confession was still slightly positive $(\mathrm{r}=.103, \mathrm{p}<.01$; previously $\mathrm{r}=.079, \mathrm{p}<.01)$; and the correlation between official misconduct and perjury/false accusations was still modestly positive $(r=.362, p<.01$; previously $\mathrm{r}=.348, \mathrm{p}<.01)$.

The results of this partial correlation on the data set provided better insight into how contributing factors interact. More importantly this information gives better insight into what can go wrong in the criminal justice process and lead to the wrongful conviction of innocents. It appears that when eyewitness misidentification occurs, it is more likely for four of the five other contributing factors to not occur. In other words, when eyewitness misidentification occurs, false confession, perjury/false accusation, official misconduct, and inadequate legal defense are all less likely to occur. Why this is the case is unclear. More in line with what was expected was the finding that when 
official misconduct occurred, it was more likely that false confessions and perjury/false accusations also would occur. Next, in order to delve deeper into the correlations between contributing factors, six more partial correlations were run, one for each of the crime-types into which the author divided the data set. Partial Correlations of the Contributing Factors in Selected Crime-Types

As seen in Table 6, when homicide cases were isolated and a partial correlation run on them, there were five statistically significant relationships. No longer significant were correlations between official misconduct and both eyewitness misidentification and false confession. Four of the statistically significant correlations in the homicide cases were similar to those in the partial correlation of using all crime types: eyewitness misidentification and false confession $(\mathrm{r}=-.182, \mathrm{p}<.01$; previously $\mathrm{r}=-.201, \mathrm{p}<.01)$; eyewitness misidentification and perjury/false accusation $(\mathrm{r}=-.343, \mathrm{p}<.01$; previously $\mathrm{r}=-$ $.52, \mathrm{p}<.01)$; eyewitness misidentification and inadequate legal defense $(\mathrm{r}=-.104, \mathrm{p}<.05$; previously $\mathrm{r}=-.083, \mathrm{p}<.01)$; and perjury/false accusation and official misconduct $(\mathrm{r}=.319$, $\mathrm{p}<.01$; previously $\mathrm{r}=.362, \mathrm{p}<.01)$. The correlation between perjury/false accusation and inadequate legal defense had not been previously statistically significant; however in homicide cases, it was found to have a slight negative correlation ( $r=-.092, \mathrm{p}<.05)$. 
Table 6. Partial Correlation of Factors for Homicide Cases $(N=538)$

\begin{tabular}{lllllll}
\hline & 1 & 2 & 3 & 4 & 5 & 6 \\
\hline Eyewitness Misidentification (1) & 1 & & & & & \\
False Confession (2) & $-.182^{* *}$ & 1 & & & & \\
Perjury/False Accusation (3) & $-.343^{* *}$ & -.069 & 1 & & & \\
False/Misleading Forensic Evidence (4) & -.043 & -.032 & .054 & 1 & & \\
Official Misconduct (5) & -.023 & .010 & $.319 * *$ & -.031 & 1 & \\
Inadequate Legal Defense (6) & $-.104 *$ & -.070 & $-.092^{*}$ & -.029 & -.052 & 1 \\
\hline
\end{tabular}

**. Correlation is significant at the 0.01 level (2-tailed).

*. Correlation is significant at the 0.05 level (2-tailed).

Control variables: Age at time crime occurred, female exoneree, and NonWhite.

Next, a partial correlation was run only on robbery cases (as can be seen in Table 7) and compared to the initial partial correlation of all crime types. In this case, only three correlations were statistically significant. No longer statistically significant were the relationships between eyewitness misidentification and both false confession and inadequate legal defense, and the relationship between false confession and official misconduct. The relationship between perjury/false accusation and official misconduct changed only slightly $(\mathrm{r}=.369, \mathrm{p}<.05$; previously $\mathrm{r}=.362, \mathrm{p}<.01)$. The relationship between eyewitness misidentification and official misconduct changed somewhat more $(\mathrm{r}=-.301, \mathrm{p}<.05$; previously $\mathrm{r}=-.187, \mathrm{p}<.01)$. Lastly, the relationship between eyewitness misidentification and perjury/false accusation changed most, becoming much more negatively related $(r=-.703, \mathrm{p}<.01$; previously $\mathrm{r}=-.52, \mathrm{p}<.01)$. 
Table 7. Partial Correlation of Contributing Factors for Robbery Cases $(N=66)$

\begin{tabular}{lllllll}
\hline & 1 & 2 & 3 & 4 & 5 & 6 \\
\hline Eyewitness Misidentification (1) & 1 & & & & \\
False Confession (2) & .069 & 1 & & & \\
& - & -.047 & 1 & & & \\
Perjury/False Accusation (3) & $.703^{* *}$ & & & & \\
False/Misleading Forensic Evidence & .096 & -.040 & -.081 & 1 & & \\
(4) & & & & & & \\
Official Misconduct (5) & $-.301 *$ & .242 & $.369 *$ & -.150 & 1 & \\
Inadequate Legal Defense (6) & .197 & .167 & -.144 & -.046 & -.103 & 1 \\
\hline **. Correlation is significant at the 0.01 level (2-tailed). & & & & \\
*. Correlation is significant at the 0.05 level (2-tailed). & & & & \\
Control variables: Age at time crime occurred, female exoneree, and NonWhite. & &
\end{tabular}

When the partial correlation was run on the sexual assault cases (results in Table 8), there were seven statistically significant correlations. The relationship between eyewitness misidentification and official misconduct was no longer significant. Three of the five correlations that were statistically significant in both partial correlation tests were quite similar: the correlation between eyewitness misidentification and false confession $(\mathrm{r}=-.227, \mathrm{p}<.01$; previously $\mathrm{r}=-.201, \mathrm{p}<.01)$, the correlation between eyewitness misidentification and perjury/false accusation $(\mathrm{r}=-.501, \mathrm{p}<.01$; previously $\mathrm{r}=-.52, \mathrm{p}<.01)$, and the correlation between false confession and official misconduct $(r=.192, p<.01$; previously $\mathrm{r}=.103, \mathrm{p}<.01)$. The other two of the five cases that were statistically significant in both correlations were somewhat different: the relationship between eyewitness misidentification and official misconduct became more negatively correlated $(\mathrm{r}=-.257, \mathrm{p}<.01$; previously $\mathrm{r}=-.083, \mathrm{p}<.01)$, and the relationship between perjury/false accusation and official misconduct became less positively correlated $(r=.194, p<.01$; previously $\mathrm{r}=.362, \mathrm{p}<.01$ ). Two correlations became statistically significant when only 
the sexual assault cases were isolated: the correlation between perjury/false accusation and false/misleading forensic evidence was slightly positive $(\mathrm{r}=.177, \mathrm{p}<.01)$, and the correlation between perjury/false accusation and inadequate legal defense was mildly positive $(\mathrm{r}=.258, \mathrm{p}<.01)$.

Table 8. Partial Correlation of Contributing Factors for Sexual Assault Cases $(N=223)$

\begin{tabular}{|c|c|c|c|c|}
\hline & 1 & 2 & 3 & 4 \\
\hline Eyewitness Misidentification (1) & 1 & & & \\
\hline False Confession (2) & $-.227 * *$ & 1 & & \\
\hline Perjury/False Accusation (3) & $-.501 * *$ & -.046 & 1 & \\
\hline False/Misleading Forensic Evidence (4) & -.019 & .046 & $.177 * *$ & 1 \\
\hline Official Misconduct (5) & .030 & $.192 * *$ & $.194 * *$ & .1141 \\
\hline Inadequate Legal Defense (6) & $-.257 * *$ & -.006 & $.258 * *$ & -.116 .0401 \\
\hline
\end{tabular}

When child sex abuse cases were isolated (Table 9), there was only one statistically significant correlation between the contributing factors. The correlation between eyewitness misidentification and perjury/false accusation had been moderately negative $(\mathrm{r}=-.52, \mathrm{p}<.05)$ in the correlation of contributing factors in all cases. The same correlation became strong in child sex abuse cases $(r=-.851, \mathrm{p} .01)$. There were no other statistically significant correlations. 
Table 9. Partial Correlation of Contributing Factors for Child Sex Abuse Cases $(N=131)$

\begin{tabular}{lllllll}
\hline & 1 & 2 & 3 & 4 & 5 & 6 \\
\hline Eyewitness Misidentification (1) & 1 & & & & & \\
False Confession (2) & -.024 & 1 & & & & \\
Perjury/False Accusation (3) & $-.851^{* * *}$ & -.122 & 1 & & & \\
False/Misleading Forensic Evidence (4) & .176 & -.084 & -.029 & 1 & & \\
Official Misconduct (5) & -.133 & .162 & .102 & .044 & 1 & \\
Inadequate Legal Defense (6) & -.153 & .065 & .151 & .078 & .053 & 1 \\
\hline
\end{tabular}

**. Correlation is significant at the 0.01 level (2-tailed).

*. Correlation is significant at the 0.05 level (2-tailed).

Control variables: Age at time crime occurred, female exoneree, and NonWhite.

The correlation of all of the cases and the correlation of only the nonviolent cases

(Table 10) had two statistically significant correlations in common: eyewitness

misidentification and perjury/false accusation became slightly less correlated $(\mathrm{r}=-.381$,

$\mathrm{p}<.01$; previously $\mathrm{r}=-.52, \mathrm{p}<.01)$, and official misconduct and perjury/false accusation

became slightly more correlated $(\mathrm{r}=.529, \mathrm{p}<.01$; previously $.362, \mathrm{p}<.01)$. Two

correlations that had previously not been so were statistically significant when only the

nonviolent crimes were correlated: the correlation between eyewitness misidentification

and false/misleading forensic evidence was modestly positive $(\mathrm{r}=.251, \mathrm{p}<.05)$, and the

correlation between official misconduct and inadequate legal defense was modestly

negative $(\mathrm{r}=-.306, \mathrm{p}<.01)$. 
Table 10. Partial Correlation of Factors for Nonviolent Crimes $(N=104)$

\begin{tabular}{lllllll}
\hline & 1 & 2 & 3 & 4 & 5 & 6 \\
\hline Eyewitness Misidentification (1) & 1 & & & & & \\
False Confession (2) & -.006 & 1 & & & & \\
Perjury/False Accusation (3) & $-.381^{* *}$ & -.117 & 1 & & & \\
False/Misleading Forensic Evidence (4) & $.251^{*}$ & -.044 & -.155 & 1 & & \\
Official Misconduct (5) & -.199 & -.121 & $.529 * *$ & -.156 & 1 & \\
Inadequate Legal Defense (6) & .038 & -.030 & -.159 & .190 & $-.306^{* *}$ & 1 \\
\hline
\end{tabular}

**. Correlation is significant at the 0.01 level (2-tailed).

*. Correlation is significant at the 0.05 level (2-tailed).

Control variables: Age at time crime occurred, female exoneree, and NonWhite.

The correlation including all crime types and the correlation of only the other violent cases (Table 11) had two statistically significant correlations in common: the correlation between eyewitness misidentification and perjury/false accusation remained moderately negative $(\mathrm{r}=-.479, \mathrm{p}<.01$; previously $\mathrm{r}=-.52, \mathrm{p}<.01)$, and the relationship between official misconduct and perjury/false accusation was more strongly positively correlated $(\mathrm{r}=.473, \mathrm{p}<.01$; previously $\mathrm{r}=.362, \mathrm{p}<.01)$. When the other violent crimes were isolated, five other correlations became statistically significant that had not previously been so when all of the crime type were included in the correlation: the correlation between eyewitness misidentification and false/misleading forensic evidence was moderately negative $(\mathrm{r}=-.401, \mathrm{p}<.05)$; the correlation between false confession and perjury/false accusation was modestly negative $(r=-.372, \mathrm{p}<.05)$; the correlation between false confession and false/misleading forensic evidence was modestly positive $(r=.387$, $\mathrm{p}<.05)$; the correlation between perjury/false accusation and false/misleading forensic evidence was modestly negative $(r=-.334, \mathrm{p}<.05)$; and the correlation between official misconduct and inadequate legal defense was moderately negative $(\mathrm{r}=-.414, \mathrm{p}<.01)$. 
Table 11. Partial Correlation of Contributing Factors for Other Violent Crimes $(N=45)$

\begin{tabular}{lllllll}
\hline & 1 & 2 & 3 & 4 & 5 & 6 \\
\hline Eyewitness Misidentification (1) & 1 & & & & & \\
False Confession (2) & -.221 & 1 & & & & \\
Perjury/False Accusation (3) & $-.479^{* *}$ & $-.372^{*}$ & 1 & & & \\
False/Misleading Forensic Evidence (4) & $-.401^{*}$ & $.387^{*}$ & $-.334^{*}$ & 1 & & \\
Official Misconduct (5) & -.168 & -.005 & $.473^{* *}$ & -.107 & 1 & \\
Inadequate Legal Defense (6) & .061 & .032 & -.190 & .284 & $-.414^{* *}$ & 1 \\
\hline
\end{tabular}

**. Correlation is significant at the 0.01 level (2-tailed).

*. Correlation is significant at the 0.05 level (2-tailed).

Control variables: Age at time crime occurred, female exoneree, and NonWhite.

When the results of each of these correlations are compared with the results of the initial partial correlation utilizing the entire data set, finding stands out. Across all of these partial correlations, eyewitness misidentification and perjury/false accusation are negatively correlated. Also, affirming a hypothesis, across all correlations except for that of the child sex abuse cases, official misconduct and perjury/false accusation were positively correlated. Four of the six crime-types resulted in new correlations not previously seen in correlation of the entire data set. Almost all of these new correlations were specific to the crime-type in which it was found, with only one overlap: official misconduct and inadequate legal defense were negatively correlated in both nonviolent crime cases and other violent crime cases. That there were new, specific correlations for four of the six crime-types suggests that different crimes may have different factors go wrong in the criminal justice process. This is important because it suggests that each crime type should be viewed and studied autonomously in regard to the process that leads to wrongful convictions. 


\section{Research Question \#3: Time to Exoneration}

Another way to examine issues with wrongful convictions is to look at whether it takes longer for the wrongfully convicted to be exonerated when certain contributing factors have been involved in a case. The last question in this research examined just that. Previous research used basic line graphs to show the average time from conviction to exoneration. However, to gain a better understanding of this question, a more detailed test was needed. A linear regression was chosen so that a number of factors could simultaneously be examined and controlled for when looking at the length of time from conviction to exoneration.

Two models were used in this test. In the first, the dependent variable was time from conviction to exoneration, and the independent variables were each of the contributing factors. All of the contributing factors were included to see the relative involvement of the each on time to exoneration. In the second model, the dependent variable was time from conviction to exoneration, and the independent variable was the number of contributing factors that had been involved in the cases. A number of control variables were used. These control variables also gave great insight into other factors that can affect the length of time from conviction to exoneration. 
Table 12. Linear Regression Results of Contributing Factor Variables and Control Variables Predicting Years from Conviction to Exoneration $(N=1107)$

\begin{tabular}{|c|c|c|c|c|c|c|}
\hline \multirow[b]{2}{*}{ Variables } & \multicolumn{3}{|c|}{ Model 1} & \multicolumn{3}{|c|}{ Model 2} \\
\hline & $b$ & $\mathrm{SE}$ & $\beta$ & $b$ & $\mathrm{SE}$ & $\mathrm{B}$ \\
\hline \multicolumn{7}{|l|}{$\begin{array}{l}\text { Contributing Factor } \\
\text { Variables }\end{array}$} \\
\hline Eyewitness Misidentification & 0.572 & 0.564 & 0.035 & - & - & - \\
\hline False Confession & 0.484 & 0.634 & 0.021 & - & - & - \\
\hline Perjury/False Accusation & 0.280 & 0.512 & 0.017 & - & - & - \\
\hline $\begin{array}{l}\text { False/Misleading Forensic } \\
\text { Evidence }\end{array}$ & -0.611 & 0.497 & -0.032 & - & - & - \\
\hline Official Misconduct & $1.673 * * *$ & 0.446 & 0.103 & - & - & - \\
\hline Inadequate Legal Defense & 0.966 & 0.580 & 0.043 & - & - & - \\
\hline Total Factors & - & - & - & $0.631 * *$ & 0.229 & 0.083 \\
\hline \multicolumn{7}{|l|}{ Control variables } \\
\hline Age at time crime occurred & $-0.096 * * *$ & 0.022 & -0.113 & $-0.091 * * *$ & 0.022 & -0.108 \\
\hline Black & $1.293 * *$ & 0.473 & 0.080 & $1.569 * *$ & 0.458 & 0.097 \\
\hline Hispanic & $-1.912 * *$ & 0.696 & -0.076 & $-1.558^{*}$ & 0.678 & -0.062 \\
\hline OtherRace & -0.671 & 0.983 & -0.017 & -0.606 & 0.986 & -0.016 \\
\hline Female Exoneree & -1.016 & 0.827 & -0.031 & -1.283 & 0.820 & -0.040 \\
\hline Homicide & $3.276^{* * *}$ & 0.808 & 0.204 & $3.080 * * *$ & 0.799 & 0.192 \\
\hline Robbery & -0.067 & 1.150 & -0.002 & -0.116 & 1.097 & -0.003 \\
\hline SexualAssault & $2.286^{*}$ & 0.969 & 0.116 & $1.874^{*}$ & 0.936 & 0.095 \\
\hline ChildSexAbuse & $2.000^{*}$ & 0.943 & 0.081 & 1.634 & 0.916 & 0.066 \\
\hline OtherViolent & -1.176 & 1.231 & -0.029 & -1.328 & 1.209 & -0.033 \\
\hline After1992 & $-6.894 * * *$ & 0.432 & -0.426 & $-6.894 * * *$ & 0.430 & -0.425 \\
\hline DNA (determinative) & $2.884 * * *$ & 0.599 & 0.162 & $1.700 * *$ & 0.614 & 0.096 \\
\hline Intercept & $12.572 * * *$ & 1.206 & - & $12.766 * * *$ & 1.203 & - \\
\hline
\end{tabular}

$* * * p<0.001 ; * * p<0.01 ; * \mathrm{p}<0.05$.

$R^{2}=.402($ Model 1$) ; R^{2}=.394($ Model 2$)$.

In the first model (seen in Table 12), where each of the contributing factors was taken into account, only one contributing factor produced a statistically significant result. Although there was only one, it was the one that had been hypothesized. When official 
misconduct was present, there was a somewhat strong indication $(\beta=.10)$ that this increased the time to exoneration by about 1.7 years. False confessions were also hypothesized to have an effect; however it was not found to be statistically significant. In Model 2, where the total number of factors was taken into account, the result was also statistically significant, providing support for the author's hypothesis in this model. There was a somewhat weak indication $(\beta=.08)$ that for each increase in the total number of contributing factors, there was an increase in time to exoneration of about 7.5 months (.631 years).

The control variables were able to create a much more vivid picture of the factors that play into the length of time it takes an innocent person to get exonerated once they have been convicted. The results were very similar in both models. In both Model 1 and 2 , there was a somewhat weak indication $(\beta=-.11)$ that as age increases by one year, time to exoneration decreases by just over a month (.096 years and .091 years respectively). In both models, there was a relatively strong indication that race has an effect on how long it takes someone to get exonerated. According to these data, it has taken African Americans about 1.3 to 1.6 more years than Caucasians to be exonerated. However, it has taken Hispanics about 1.6 to 1.9 years less than Caucasians to be exonerated.

It is also necessary to look at the length of time between conviction and exoneration by the crime type to see whether or not this can have an effect. Due to the severity of homicide cases, it was hypothesized that these cases would take longer to get exonerated. There is a strong indication $(\beta=.20)$ that this hypothesis is correct. 
According to these data, when someone has been wrongfully convicted of homicide, it has added on about three more years to the length of time from their conviction to their exoneration. It was not hypothesized, but there is a very strong indication $(\beta=.12$ and .10) that sexual assault cases add about two more years from the time of conviction to exoneration.

To look more closely at factors that could have an effect on the amount of time it took a person to be exonerated, the cases were divided into convictions occurring in 1992 and before and cases occurring in 1993 and after. This was to take into account the use of DNA in the criminal process, as opposed to the exoneration process. As hypothesized, it was moderately indicated $(\beta=-.43)$ that cases in which the conviction occurred before 1992 took almost seven years longer to exonerate. This finding matches up with the next finding- there is a somewhat strong indication ( $\beta=.16$ and .10 respectively) that when DNA was determinative in the exoneration (i.e. was most likely not used in the adjudication process), the case took about 1.7 to 2.9 years longer than when it was not. 


\section{CHAPTER V}

\section{SUMMARY, CONCLUSIONS, AND RECOMMENDATIONS}

Summary of the Research Problems, Methods and Findings

This research used the existing database of exonerations, the National Registry of Exonerations (NRE), to examine three research questions through the lens of factors that have contributed to wrongful convictions. If more information could be gained about what has been known to contribute to wrongful convictions, this knowledge could be used to help prevent future wrongful convictions. Six factors have been recognized in prior research as those most often associated with wrongful convictions. These six categories are: eyewitness misidentification, false confessions, perjury/false accusation, false/misleading forensic evidence, official misconduct, and inadequate legal defense. This research examined the frequency with which each of these factors were present in a wrongful conviction, how these factors interact, and how they affect the length of time an innocent person must wait before being exonerated.

The research questions were:

1. What are the characteristics of the exonerations in the NRE, particularly how prevalent is each contributing factor? Is this in line with previous research?

2. How do the factors contributing to wrongful convictions correlate with each other? Is this relationship different by crime type? 
3. What factors are associated with the number of years from conviction to exoneration?

To examine these questions fully, a number of statistical analyses were used including descriptives and frequencies, correlations, and linear regressions. The results provided a glimpse into why wrongful convictions continue, even in the age of DNA and forensics.

The study of contributing factors showed where in the criminal justice process mistakes were made, oversights occurred, or when defendants merely slipped through the cracks. Inspecting what occurred in cases before a defendant was wrongfully convicted allows researchers to recommend steps to prevent wrongful convictions in the future. The contributing factors a general idea of where there are problems within the American criminal justice system. However, without a larger context for those individual contributing factors, some depth of understanding may be lost. The occurrence of one contributing factor could happen under a number of different circumstances. For example, there is no context to know if something contributed to a wrongful conviction because of an honest oversight or mistake, or if the factor was more intentional or even vindictive in nature. Due to the necessarily limited scope of this research, it was decided to limit the work to the six categories of contributing factors. These six factors provided useful, valid results.

Some results were less expected than others. There had been a fair amount of previous research, so it was decided to focus on the past to shed light on the future. In part, the research questions were chosen to see if the results from this extensive data set would be in line with past research. If it was not, then it would raise questions about 
what has been changing. There are a number of unknowns when it comes to this topic, including how often wrongful convictions occur, which contributing factors have an effect on exoneration, and why some cases slip through the cracks while others do not. For this reason a variety of methods were chosen to give the most comprehensive insight possible. Descriptives and frequencies were necessary to break down the data to determine how often certain factors occurred, who was being affected, what the impact of DNA has been, and how many factors have typically been involved in a case.

Correlations were used to gain insight into how contributing factors might occur together, and what that means for the future of research and preventive measures in this area. Finally, linear regressions were used to analyze the impact that certain variables may have on the length of time from conviction to exoneration.

Summary of Findings and Recommendations for Future Research One of the main tasks in this research was to see whether the results were in line with what other research had concluded. The results were relatively in line with previous research, however it was apparent that the more exonerations that are uncovered, the more that is being discovered about wrongful convictions. One of the most striking results was the finding that official misconduct occurred in $43.4 \%$ of cases. This was not expected. Officials of the criminal justice system have been entrusted by the public to live by a higher standard, so that they objectively find truth and justice every day. This research suggests that the public might not so readily put their trust in these officials. The public needs to know that although the justice system is not perfect, justice officials are focused on their mission and not on any number of the things that can distract them 
from it. Without the trust of the public, the justice system loses its credibility. This research does not suggest the public turn its back on these hardworking agents of justice keep in mind that this is $43.4 \%$ of known exonerations - however; it does suggest that agencies need to take a hard look at what is occurring inside their walls. Officials need to be vigilant in their fight for justice. New policies, awareness, and possible reform are the ways to solve this issue. There needs to be a united front against letting innocent people be convicted of crimes they did not commit.

Official misconduct and perjury/false accusation were positively correlated in five of the six crime types. This is more in line with what one might expect. However, the fact that perjury and false accusation are grouped as one clouds the accuracy of this result. It cannot be determined if the official misconduct was the result of tunnel vision, a false accusation, or if the misconduct went so far as an official lying on the stand.

False confessions are often linked with official misconduct in people's minds, if not in research findings. The number of false confession cases in this database seems low, occurring in only $13 \%$ of cases. Although it is conjecture, it seems that it may be more difficult to exonerate someone after they have falsely confessed because of the weight given to confessions by criminal justice officials. It is known that many false confessions occur; however the issues surrounding the weight of these confessions have already been discussed. This may lead to a skewed understanding of false confessions in the criminal justice system.

False confessions are without a doubt something very difficult to overcome, even with the scientific knowledge that exists today. There are a number of ways to help 
decrease the number of false confessions that are obtained by the police. The American Bar Association found that when interrogations are videotaped, police are less likely to use tactics that lead to false confessions. They also found that videotapes make it more likely that false confessions, when they are made, are caught at a later time. Thus, the ABA House of Delegates created a policy statement that urged all law enforcement agencies to use videotapes during the entirety of interrogations, no matter where they take place (police department, court house, detention center, or elsewhere that the suspect is being held for questioning) (American Bar Association, 2006). Another way to prevent police from trying to force confessions is for police to be trained on tunnel vision. Because tunnel vision has been associated with miscarriages of justice, if police are trained to stay objective and focus on the evidence and not become subjective, the likelihood that they will obtain false confessions should decrease.

The issues surrounding DNA have already been discussed as well. Homicide and sexual assaults accounted for the majority of cases of exoneration. If, for example, robberies had a similar way to test for the accuracy of a suspect, it raises the question how many more robbery exonerations there would be.

Eyewitnesses have been discussed for hundreds of years as problematic (Borchard, 1932; Gross et al, 2005; Rattner, 1988). However, even with all of the known issues, eyewitness misidentification still occurred in $40.8 \%$ of cases. Eyewitness misidentification and perjury/false accusation were negatively correlated. This goes against what earlier research had said. One possible explanation for this is that perjury and false accusations have been grouped into one category. Would false accusations be 
more likely to occur with eyewitness misidentification? If not, then why is it less likely for it to occur when eyewitness misidentification occurs?

Eyewitness misidentification continues to be an issue in the criminal justice process. Most researchers call for the use of more scientific approaches when using eyewitness information, specifically the process of when and how eyewitnesses identify the suspect (Borchard, 1932; Acker \& Redlich, 2001; Rattner, 1988). Acker and Redlich (1988) cited a paper that was published by the American Psychology-Law Society (a division of the American Psychological Association) in 1998. This paper offered four independent rules for reform. First, whoever conducts the lineup must not in any way encourage or discourage the witness in any way. Second, instructions must be given before the viewing, so that the witness knows what to expect, that they should not feel pressured, and so that they know that the true suspect may not even be in the lineup. Third, the structure of the lineup or photospread must in no way suggest one person over another. Lastly, confidence statements must be obtained from the witness. In other words, the conductor must ask the witness how confident he or she is in his or her decision (Acker and Redlich, 2001).

Rattner (1988) has more suggestions for the reformation of eyewitness identification. He suggests that there be more caution in cases where eyewitness identification is the sole evidence against a person. He says that in these cases, there should be a special pretrial session where a judge or jury hears all of the information related to the issue. They should then decide if it is an adequate, reliable and valid enough eyewitness identification to move forward with trial. He also suggests that in 
cases where eyewitness identification is involved, but is not the only piece of evidence against a suspect, the court should either allow the use of an expert witness, or the judge should issue precise, cautionary instructions regarding eyewitness identification.

False and/or misleading forensic evidence is an interesting category. When it is paired with official misconduct, the results can be disastrous. However, there can also be honest mistakes in this area. This field is still being developed. It must still be held to the highest standards, however. Problems in this area may not appear for a while. As was touched on earlier, solutions for false and misleading forensic evidence include using checks and balances in forensic labs, so that the likelihood of someone falsifying evidence decreases. Also, training judges and informing juries on forensic evidence's validity and making sure that the whole story is told at trial are important. In addition, defense attorneys need to challenge forensic evidence that does not definitively show that their client committed a crime. If there is much circumstantial evidence against someone with only forensic evidence, it is up to the defense attorney to fight against it, so that his or her client does not take a plea bargain merely because there is too much evidence against them.

Inadequate legal defense is a relatively new topic, and not much was gleaned from the analysis of these data. However, there are many recommendations for the future in this area. In the case of district attorneys, it is important to keep checks and balances in these offices, so that justice is always the main goal. If these officers feel pressure to perform, and that is coming at the expense of truth and justice, there is a serious problem. Educating the public about what really goes on in district attorney's offices and with the 
entire criminal justice process is also important, so that the public and the criminal justice system can work together to better their society. Prosecutors also need incentives to focus on finding the truth rather than winning one hundred percent of their cases. Too often, prosecutors are judged on their perceived performance. Only if they are getting convictions in every case are they seen as good attorneys. This is far from the truth. Pushing for "wins" over trying to find the truth, especially in the criminal justice system is abominable. As has been concluded in other research, it would be helpful in the fight against wrongful convictions to lower the caseload for public defenders.

\section{Conclusions and Implications}

This research has shown that it is important to continue the study of wrongful convictions and factors that contribute to them. This research suggested areas in which there have been improvements (inadequate legal defense as a contributing factor) and what is not (the use of eyewitnesses). There are also areas in which the data might be improved. For example, the category of perjury/false accusation yielded confusing results. It may be that these two ideas need to be separated. There appears to be a need for a third separate category, snitches. Snitches are a large issue which was touched on in this paper and in other wrongful conviction research. However, in reality, this topic needs more attention. Snitches are given incentives to lie. They may incriminate an innocent person all because in return they get a reduced sentence, no jail time, or any number of other perks. Snitches have every reason to look out for themselves. Not all snitches are bad, or their use should be ended, but there are very real issues when it 
comes to snitches, and their use may be increasing the number of wrongful convictions. This topic needs its own category in the study of wrongful convictions.

Future research should involve more qualitative data to gain more context in which to understand the factors that lead to wrongful convictions. With a fuller understanding of context, the role of contributing factors can be better understood, and more knowledge can be gained about what is occurring (good and bad), and what needs to be changed. 


\section{REFERENCES}

Acker, J. R., \& Redlich, A. D. (2001). Wrongful conviction: Law, science and policy. North Carolina: Carolina Academic Press.

American Bar Association. (2006). Achieving justice: Freeing the innocent, convicting the guilty. Washington, DC: American Bar Association.

Associated Press. (1989, August 15). Gary Dotson cleared in notorious rape case. The San Francisco Chronicle, A4. Retrieved from http://infoweb.newsbank.com/iwsearch/we/InfoWeb?p_product=AWNB\&p_theme=aggregated5\&p_action=doc\& p_docid=0EB4F1ACB1D6BDB9\&d_place=SFCB\&f_issue $=1989-08$ $15 \& f$ _publisher=

Berry, Sheila, Martin. (2003). 'Bad lawyering': How defense attorneys help convict the innocent. Northern Kentucky Law Review, 30, 487.

Borchard, E.M. (1932). Convicting the innocent: Sixty-five actual errors of criminal justice. Garden City, NJ: Garden City.

Brandon, G. (2011). Convicting the innocent: Where criminal prosecutions go wrong. Cambridge: Harvard University Press.

Brandon, R., \& Davies, C. (1973). Wrongful imprisonment: Mistaken convictions and their consequences. Hamden, Connecticut: Archon Books.

Colvin, E. (2009). Convicting the innocent: A critique of theories of wrongful convictions. Criminal Law Forum, 20(2), 173-192.

Enlightenment. (2013). Reference.com, Dictionary.com, LLC. Obtained from: http://www.reference.com/browse/Enlightenment?s=t

Feld, B.C. (2013). Real interrogation: What actually happens when cops question kids. Law \& Society Review, 47(1), 1-35.

Gould, J.B., \& Leo, R.A. (2010). One hundred years later: Wrongful convictions after a century of research. Journal of Criminal Law \& Criminology, 3, 825.

Gross, S.R., Jacoby, K., Matheson, D.J., Montgomery, N., \& Patil, S. (2005). Exoneration in the United States 1989 through 2003. Journal of Criminal Law \& Criminology, 95(2), 523-560.

Gross, S.R., \& Shaffer, M. (2012). Exonerations in the United States, 1989-2012: Report by The National Registry of Exonerations. Retrieved from http://www.law.umich.edu/special/exoneration/Documents/exonerations_us_1989 _2012_full_report.pdf

History. (2013). Enlightenment. A\&E Television Networks, LLC. Obtained from: http://www.history.com/topics/enlightenment

Huff, R.C., Rattner, A., \& Sagarin, E. (1986). Guilty until proved innocent: Wrongful conviction and public policy. Crime \& Delinquency, 32, 518-544. 
Huff, R.C., Rattner, A., \& Sagarin, E. (1996). Convicted, but innocent: Wrongful conviction and public policy. Thousand Oaks, California: SAGE Publications.

Kassin, S.M. (2008). False confessions: Causes, consequences, and implications for reform. Current Directions in Psychological Science, 249, 249-253.

Krieger, S. (2011). Why our justice system convicts innocent people, and the challenges faced by innocence projects trying to exonerate them. New Criminal Law Review, 14,333 .

Loftus, E. (2003). Our changeable memories: Legal and practical implications. Nature Reviews Neuroscience, 4(3), 231.

McKay, J. (2004). The CSI Effect. Government Technology, 21(2), 18-23.

McNamara, J. \& Lawrence, J. (2012). False allegations of adult crimes. FBI Law Enforcement Bulletin, 81(9), 1-6.

Medwed, D.S. (2006). Anatomy of a wrongful conviction: Theoretical implications and practical solutions. Villanova Law Review, 51, 100.

Mumma, C.C. (2004). The North Carolina actual innocence commission: Uncommon perspectives joined by a common cause. Drake Law Review, 52, 647-656.

Natapoff, A. (2011, February 18). Who 'snitching' really betrays. Retrieved from http://www.cnn.com/2011/OPINION/02/18/natapoff.snitching.withers/index.html

National Registry of Exonerations, The. (2013). UPDATE:2012. Retrieved from: http://www.law.umich.edu/special/exoneration/Documents/NRE2012UPDATE4_ 1_13_FINAL.pdf

Northwestern University School of Law Center on Wrongful Convictions. (2004). The Snitch System [Booklet]. Chicago: Northwestern University School of Law.

Packer, H. (1968). The limits of the criminal sanction. Stanford: Stanford University Press.

Poveda, T.G. (2001). Research note: Estimating wrongful convictions. Justice Quarterly, 18(3), 689-708.

Ramsey, R.J., \& Frank, J. (2007). Wrongful conviction: Perceptions of justice professionals regarding the frequency of wrongful conviction and the extent of system errors. Crime \& Delinquency 53(3), 436-470.

doi:10.1177/0011128706286554

Radelet, M.L., Bedau, H.A., \& Putnam, C.E. (1992). In spite of innocence. Boston: Northeastern University Press.

Rassin, E. (2010). Blindness to alternative scenarios in evidence evaluation. Journal of Investigative Psychology and Offender Profiling, 7, 153-163.

Rattner, A. (1988). Convicted but innocent: Wrongful conviction and the criminal justice system. Law and Human Behavior, 12(3), 283-294.

Ronfeldt, D. (2006). In search of how societies work: Tribes- The first and forever form [Working Paper]. RAND Pardee Center. Obtained from: http://www.rand.org/content/dam/rand/pubs/working_papers/2007/RAND_WR43 3.pdf

Scientific Revolution. (2013). Reference.com, Dictionary.com, LLC. Obtained from: http://www.reference.com/browse/scientific+revolution?s=t 
Smith, B.P. (2005). The history of wrongful convictions. Hastings Law Journal, 56, 1185.

University of the Michigan Law School and the Center on Wrongful Convictions at Northwestern University School of Law. (2012). The National Registry of Exonerations [Data file]. Retrieved from http://www.law.umich.edu/special/exoneration/Pages/detaillist.aspx

Watkins v. Sowders, 499 U.S. (1981).

Zalman, M., Smith, B., \& Kiger, A. (2008). Officials' estimates of the incidence of "actual innocence" convictions. Justice Quarterly, 25(1), 72-100.

Doi:10.1080/07418820801954563 